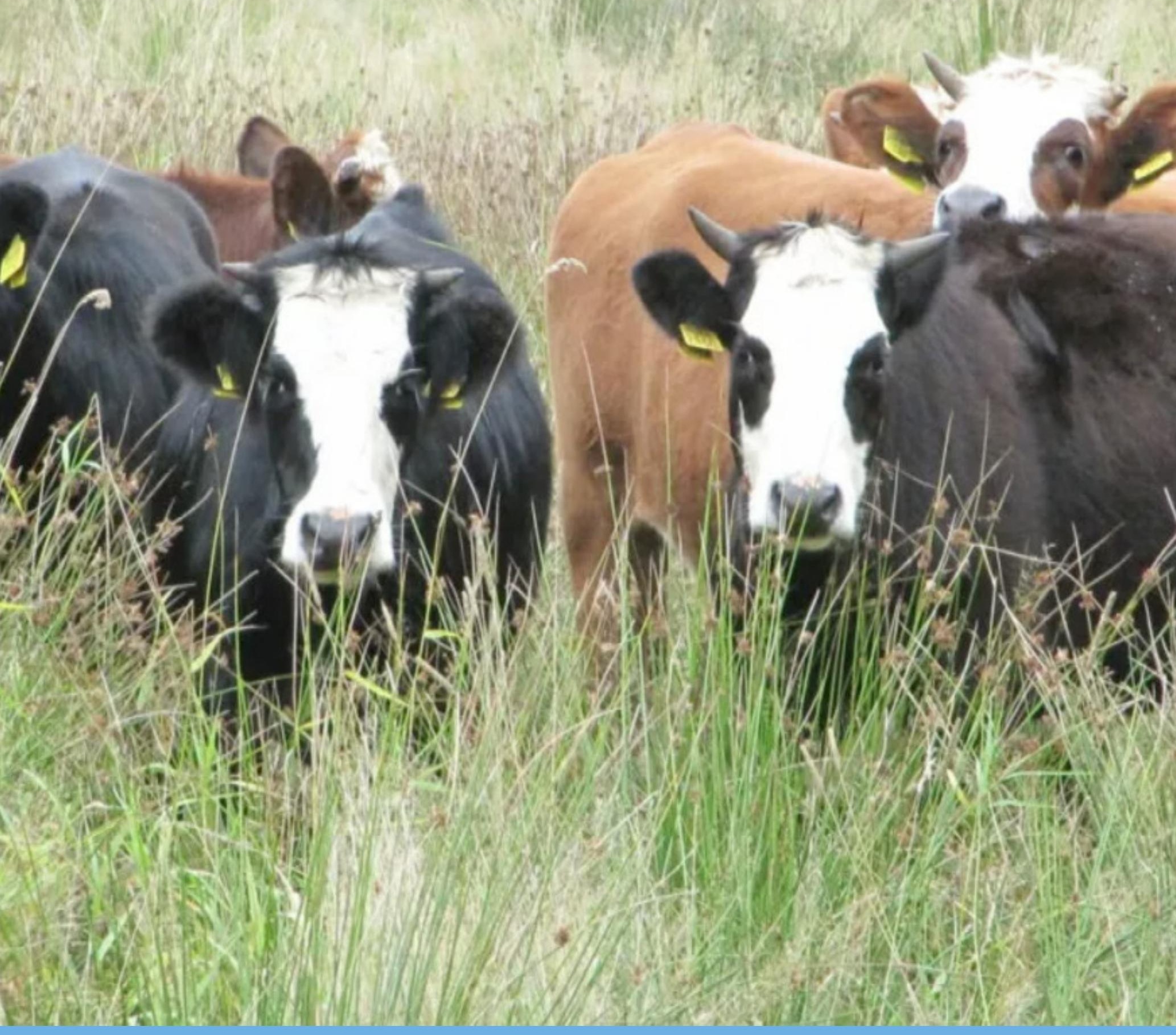

Betrokkenheid van consumenten bij beoordeling van garantiesystemen voor duurzaamheid

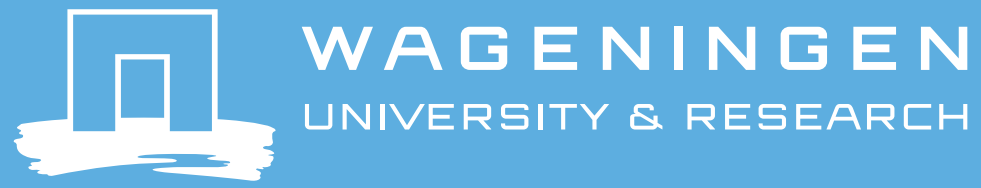





\section{Betrokkenheid van consumenten bij beoordeling van garantiesystemen voor duurzaamheid}

Reina T. Ferwerda-van Zonneveld ${ }^{1}$, Theun V. Vellinga ${ }^{1}$ en Bastiaan G. Meerburg ${ }^{1}$

1 Wageningen Livestock Research

Dit onderzoek is uitgevoerd door Wageningen Livestock Research en gesubsidieerd door het ministerie van Landbouw, Natuur en Voedselkwaliteit, in het kader van het Beleidsondersteunend onderzoek thema 'AF-18156 Call NRO SIA' (projectnummer BO-56-001-035-WLR). 
Ferwerda-van Zonneveld, R.T., Vellinga, T.V. en Meerburg, B.G., 2021. Betrokkenheid van consumenten bij beoordeling van garantiesystemen voor duurzaamheid. Wageningen Livestock Research, Openbaar Rapport 1336.

Samenvatting NL Dit rapport beschrijft de betrokkenheid van consumenten bij keurmerken aan de hand van een literatuurstudie en twee interviews. Er blijkt uit de literatuur dat consumenten op dit moment zeer beperkt betrokken zijn bij de beoordeling van duurzaamheidskenmerken en dit werd in de interviews bevestigd. De onwetendheid over de integrale afwegingen die bij deze beoordeling moet worden gemaakt, leidt er mogelijk toe dat keurmerken in de winkel uiteindelijk minder worden vertrouwd door het grote publiek.

Summary EN This report describes the involvement of consumers in labelling on the basis of a literature study and two interviews. It appears from the literature that consumer participation in the assessment of sustainability characteristics is currently very limited, which is confirmed by the interviews. The ignorance of the integral considerations that must be made in this assessment may lead to labels being less trusted in the store by the general public.

foto: Stichting Zeldzame Huisdierrassen, SZH.

Dit rapport is gratis te downloaden op https://doi.org/10.18174/554330 of op www.wur.nl/livestock-research (onder Wageningen Livestock Research publicaties).

\section{(cc) BY-NC}

Dit werk valt onder een Creative Commons Naamsvermelding-Niet Commercieel 4.0 Internationaallicentie.

(C) Wageningen Livestock Research, onderdeel van Stichting Wageningen Research, 2021

De gebruiker mag het werk kopiëren, verspreiden en doorgeven en afgeleide werken maken. Materiaal van derden waarvan in het werk gebruik is gemaakt en waarop intellectuele eigendomsrechten berusten, mogen niet zonder voorafgaande toestemming van derden gebruikt worden. De gebruiker dient bij het werk de door de maker of de licentiegever aangegeven naam te vermelden, maar niet zodanig dat de indruk gewekt wordt dat zij daarmee instemmen met het werk van de gebruiker of het gebruik van het werk. De gebruiker mag het werk niet voor commerciële doeleinden gebruiken.

Wageningen Livestock Research aanvaardt geen aansprakelijkheid voor eventuele schade voortvloeiend uit het gebruik van de resultaten van dit onderzoek of de toepassing van de adviezen.

Wageningen Livestock Research is NEN-EN-ISO 9001:2015 gecertificeerd.

Op al onze onderzoeksopdrachten zijn de Algemene Voorwaarden van de Animal Sciences Group van toepassing. Deze zijn gedeponeerd bij de Arrondissementsrechtbank Zwolle. 


\section{Inhoud}

Woord vooraf $\quad 5$

$\begin{array}{ll}\text { Samenvatting } & 7\end{array}$

1

Inleiding

11

2

Werkwijze

13

$\begin{array}{lr}\text { Resultaten literatuurstudie } & 14\end{array}$

3.1 Voedselsystemen $\quad 14$

3.2 Duurzaamheidsinstrumenten $\quad 15$

3.2.1 Selectie van duurzaamheidsinstrumenten 15

3.2.2 Duurzaamheidscertificering door derde partijen $\quad 15$

3.3 Betrokkenheid consument bij garantiesystemen voor duurzaamheid 16

3.3.1 Burgerparticipatie 16

3.3.2 Betrokkenheid consument bij duurzaamheidscertificering door $\begin{array}{ll}\text { derde partijen } & 17\end{array}$

$\begin{array}{ll}\text { 3.3.3 Voedseldemocratie } & 17\end{array}$

$\begin{array}{lll}3.4 & \text { Alternatieve en participatieve garantiesystemen } & 18\end{array}$

$\begin{array}{ll}\text { 3.4.1 Interne controlesystemen (ICS) en participatieve } & \\ \text { garantiesystemen (PGS) } & 18\end{array}$

3.4.2 Rol relaties en bemiddelingsbronnen in verduurzaming
voedselketens

3.4.3 Review marketing - Word of mouth (WOM) 19

$\begin{array}{ll}3.5 & \text { Duurzaamheid als waarde }\end{array}$

3.5.1 Consumententrends 20

3.5.2 Op waarden gebaseerde voedselketens 20

3.6 Alternatieve garantiesystemen zonder gecontroleerde productgarantie $\quad 21$

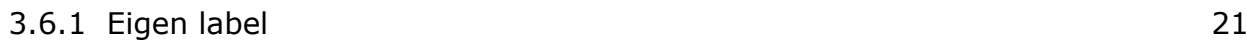

3.6.2 Ongecertificeerde bedrijfseigen duurzaamheidsclaims versus externe derde partij CSR labels $\quad 22$

3.7 Voor- en nadelen van het labelen van het voedselproductieproces 23

$4 \quad$ Resultaten interviews $\quad 25$

4.1 Resultaten $\quad 25$

4.2 Quotes 26

$\begin{array}{llr}5 & \text { Discussie en conclusie } & 28\end{array}$

$\begin{array}{ll}\text { Literatuur } & 30\end{array}$ 



\section{Woord vooraf}

In dit rapport, gefinancierd vanuit het LNV-budget Kennis Op Maat om samenwerking tussen wetenschap en groene HBO-instellingen te bevorderen, wordt gekeken of en op welke wijze consumenten op dit moment betrokken zijn bij de duurzaamheidscertificering van voedsel. Uit het onderzoek blijkt dat dit op dit moment zeer beperkt is, maar dat er wel mogelijkheden zijn om dit verder uit te breiden. Dat zou een goede ontwikkelrichting zijn, mede omdat de huidige duurzaamheidskeuzes vaak door maatschappelijke organisaties (NGO's) worden gemaakt. Daarbij moet in ogenschouw worden genomen dat deze organisaties vaak met een bepaald doel zijn opgericht en integrale keuzes over duurzaamheid daarom lastig te maken zijn. Consumentenpanels zijn hiervoor mogelijk een oplossing, zoals in dit rapport is aangegeven.

Ingeborg de Wolf PhD MSc MSc

Hoofd afdeling Veehouderij \& Omgeving

Wageningen Livestock Research 


\section{Samenvatting}

\section{Rol garantiesystemen}

In de afgelopen jaren is er in de agri-food sector een breed scala aan garantiesystemen ontwikkeld gebaseerd op diverse aspecten van duurzaamheid. Het is van belang op welke manier bedrijven ethisch handelen in hun bedrijfsvoering implementeren. Eén van de manieren waarop ze dat kunnen doen is door gebruik te maken van duurzaamheidsinstrumenten, zoals keurmerken, certificatieschema's of standaarden.

Keurmerken zijn een belangrijk communicatiemiddel naar afnemers en consumenten. Ze zijn daarmee ook belangrijk voor verdienmodellen en economisch draagvlak voor verduurzaming, ook binnen de veehouderij. De rundveehouderij heeft specifiek behoefte aan een meer integrale benadering om zo de bijdrage aan natuur, landschap en biodiversiteit te kunnen integreren in communicatie van vleesveehouders naar de consument. In hoeverre dat verwerkt kan worden in een keurmerk is een belangrijke vraag.

\section{Doel onderzoek}

Het doel van dit onderzoek is de rol, wensen en de invloed van de consument op keurmerken te bekijken. Er vindt een verkenning plaats op welke manieren de rol van de consument kan worden versterkt bij de ontwikkeling en implementatie van keurmerken, bijvoorbeeld door burgerparticipatie, online beoordelingsplatform, participatieve monitoring, betrokkenheid van bepaalde nongouvernementele organisaties (NGO's), etc.

De hoofdvragen zijn de volgende:

1) Hoe kan de consument betrokken worden in de beoordeling/verbetering van duurzaamheidskeurmerken?

2) Hoe kan de consument betrokken worden bij het meten van duurzaamheid?

Voor het beantwoorden van de vragen is een literatuurstudie gedaan en zijn aanvullend ter toetsing twee semi-gestructureerde interviews gehouden met in het onderzoek participerende rundveehouders.

\section{Uitkomsten literatuur}

Uit de literatuur blijkt dat participatie van de consument bij keurmerken op verschillende manieren mogelijk is. Aan de ene kant kan een consument passief participeren, en dat doen door producten te kopen die zijn geproduceerd in een voedselsysteem dat aansluit bij zijn/haar gedachtegoed. Deze aansluiting kan al dan niet zijn geborgd via de inzet van duurzaamheidsinstrumenten of garantiesystemen zoals keurmerken. Aan de andere kant kan een consument actief participeren, via 'community supported agriculture' initiatieven, kortweg CSA genoemd. In deze meer alternatieve voedselsystemen, waarin vaak een korte ketenbenadering de basis is, delen producenten en consumenten verantwoordelijkheid en streven ze naar een eerlijkere beprijzing en vergoeding voor de producent. De industrie en retail is dan in feite tussen de producent en consument uitgehaald.

Agrarische ondernemers besluiten tot de inzet van duurzaamheidsinstrumentarium zoals keurmerken, standaarden en certificatieschema's op twee mogelijke gronden: a) ze hopen er economisch voordeel uit te krijgen door een hogere prijs voor hun product, en/of, b) ze zien de noodzaak in van duurzame productie en proberen de impact van hun bedrijf op bepaalde terreinen te veranderen.

Het gebruik van keurmerken of standaarden met certificering is een van de meest breed gepromote instrumenten voor duurzame agrarische ontwikkeling. Echter, hoe geloofwaardig een transparant, verantwoordelijk en wetenschappelijk onderbouwde duurzaamheidscertificering door een derde partij ook kan zijn, deze is toch te ondermijnen. Doordat consumenten steeds minder verbonden zijn met het voedselproductiesysteem en het voedselproductiesysteem zelf steeds complexer en internationaler geworden is, raken ze in toenemende mate gescheiden van de gevolgen die hun dieet keuzes hebben. 
Consumenten goed geïnformeerd duurzame keuzes laten maken, vereist transparantie vanuit de gehele voedselketen.

\section{Burgerparticipatie}

Burgerparticipatie is een middel om besluitvormingsprocessen van bedrijven te verbeteren. Volgens sommige auteurs creëert burgerparticipatie bewustzijn over duurzaamheidsproblemen en helpt de acceptatie en betrokkenheid te vergroten met betrekking tot voorgenomen plannen.

Belangrijke elementen bij het betrekken van burgers zijn informatievoorziening, consultatie en actieve betrokkenheid van burgers in besluitvormingsprocessen.

Initiatieven waarbij de burgers-consumenten direct betrokken zijn bij de voedselproductie activiteiten laten een verschuiving zien in de rol van consumenten van passieve eindgebruikers en vooral kopers van voedselproducten naar pro-actieve burger-consumenten, die van plan zijn de controle over hoe voedsel wordt geproduceerd en geleverd, te herwinnen. Tegelijkertijd, echter, betekenen initiatieven vaak een cruciale verschuiving aan de producentkant - van landbouw als alleen het verkopen van grondstoffen en producten aan de voedselindustrie tot een activiteit met een bredere sociale en politieke betekenis.

Parallel aan de groei van alternatieve voedselsystemen is de belangstelling voor en adoptie van alternatieve en participatieve praktijken, gewijd aan het garanderen van de authenticiteit van biologische producten, gegroeid. Die praktijken bestaan uit interne controle systemen (ICS) oftewel groepscertificering en participatieve garantiesystemen (PGS).

Relaties en bemiddelingsbronnen (zoals een labelsysteem) spelen een rol in de verduurzaming van voedselketens. Het labelsysteem is een bron van nieuwe kennis en nieuwe relaties tussen stakeholders en ondersteunt twee belangrijke principes: transparantie en participatie.

Om de houding tot een product te beïnvloeden is communicatie tussen consumenten (mond-tot-mond) een heel krachtig instrument. Via sociale media en online platforms kunnen consumenten steeds vaker hun mening geven over producten of diensten in de vorm van beoordelingen en argumenten; beoordelingen zijn een noodzakelijk kenmerk van een website om consumenten te lokken en behouden. Wanneer het sociale en financiële risico groter is, zullen consumenten voorzichtiger zijn met het geven van beoordelingen. Aan de andere kant zullen consumenten bij een hoog - vooral sociaal - risico eerder de statistieken geloven dan dat ze zich laten beïnvloeden door een of andere beoordeling. Daarom is het nog maar de vraag of een online platform waarbij consumenten hun mening kunnen geven over de duurzaamheid van producten een geschikt instrument is om de transitie naar een duurzamer voedselproductiesysteem te bevorderen.

\section{Consumententrends}

Consumententrends kunnen de keten flink veranderen. Deze trends zijn momenteel gemak versus beleving, gezondheid en vitaliteit - lifestyle, meer groenten en minder koolhydraten. Men eet niet meer, maar anders, bijvoorbeeld duurzamer. De groei zit vooral in waarden en niet in volume. Belangrijke waarden zijn smaak, een verhaal en beleving. Transparantie is gevraagd met betrekking tot milie (milieuimpact), gezonder voedsel, dierenwelzijn en voedselverspilling.

Consumenten zijn in toenemende mate geïnteresseerd in 'waarden' gekoppeld aan het voedsel dat ze eten en zijn vaker bereid meer te betalen voor voedsel waar een verhaal (story) aan verbonden is dat de boerderij koppelt aan het eten. Daarbij gaat het o.a. over waarden als lokaal geproduceerd zijn, omvang van de boerderij (klein of gemiddeld) of een duurzame productiewijze. Groothandel kanalen die marketing opties bieden die aan deze waarden voldoen, worden values-based supply chains (VBSCs) genoemd. VBSCs bieden een aantal belangrijke voordelen aan deelnemende agrariërs, zoals transparantie en communicatie over waarden en hogere prijzen voor hun producten.

De belangrijkste kwestie is of en hoe VBSCs hun communicatie over hun waarden kunnen verbeteren en de vraag naar op waarden gebaseerde producten kunnen vergroten. Daarom is er meer transparantie nodig in de gehele voedselketen. Consumenten zijn zich nog steeds niet bewust van waar hun voedsel vandaan komt of van de waarden die eraan gekoppeld zijn. Ze moeten de reële prijs van voedsel begrijpen. Hiervoor is volgens de onderzoekers onderwijs van consumenten, beginnend bij de jeugd, over de verbanden tussen een gezonde omgeving, de economie, gemeenschap en hun eigen gezondheid nodig. 
Naast de alternatieve garantiesystemen zoals groepscertificering (ICS), participatieve garantiesystemen (PGS), values-based supply chains (VBSCs) en review marketing zijn er alternatieve systemen zonder gecontroleerde garantie van producten al dan niet met bedrijfseigen duurzaamheidsclaims.

Het aantal agrariërs dat in Nederland onder een eigen label (farm brand) producten verkoopt, lijkt toe te nemen. Agrariërs maken bij de marketing van hun label gebruik van 'story telling' en een aantal van hen claimt daarbij duurzaamheidsaspecten zonder daarbij aan eisen te voldoen, zoals die voor keurmerken gelden. De onderliggende vraag is natuurlijk welke definities men hierbij hanteert en hoe zij claims borgen.

Literatuuronderzoek toont aan dat consumenten nog steeds op een wat naïeve manier liever interne claims als vanzelfsprekend beschouwen dan dat ze vraagtekens zetten bij de authenticiteit ervan. Daarom concluderen de betreffende onderzoekers (Gosselt et al., 2019) dat het belangrijk is om een multilevel beoordelingssysteem te introduceren dat voorziet in zowel positieve als negatieve externe duurzaamheidinformatie.

\section{Labelen}

Het labelen van het voedselproductieproces kent zowel voor- als nadelen. De goede kanten zijn dat, onder toezicht van een daarvoor geschikte derde partij of de overheid, proces labels effectief bij kunnen dragen aan het dichten van de informatiekloof tussen producenten en consumenten, de consument tevreden kunnen stellen voor wat betreft hun vraag naar het uitgebreider en stringenter garanderen van kwaliteitseisen en waarde kunnen creëren voor zowel consumenten als producenten. De keerzijde van proces labels is dat consumenten de labels verkeerd kunnen interpreteren en daardoor op basis van hun persoonlijke voorkeuren ander voedsel kopen. De lelijke kanten van proces labels zijn volgens de onderzoekers dat het voedsel dat volgens de conventionele productieprocessen is geproduceerd, kan stigmatiseren ondanks dat er geen wetenschappelijk bewijs is dat dit voedsel kwaad kan of een andere samenstelling heeft.

Consumenten zijn duidelijk geïnteresseerd in meer kennis over hun voedsel en zijn bereid meer te betalen voor voedsel waarvan zij geloven dat het overeenkomt met hun voorkeuren en waarden (en vermijden voedsel dat dat niet doet).

De vermenigvuldiging van het aantal private labels en initiatieven zijn in de meeste gevallen niet bedoeld om de consument te desoriënteren, maar een zorgvuldige overweging van de complexe condities waaronder de agri-food leveranciersketen opereert. Echter, als er teveel labels zijn loop je de kans dat het vertrouwen van consumenten in labels sterk afneemt en men uiteindelijk kiest voor een meer gangbaar type product.

\section{Interviews}

Beide geïnterviewde rundveehouders geven aan een onafhankelijke 'maatlat' ofwel integraal keurmerk systeem te willen. Zij zien ontwikkeling daarvan als een verantwoordelijkheid van de overheid, gevoed door kennis vanuit de wetenschap. Beide veehouders steken niet in op het actief laten participeren van burgers. Zij willen dat de burger-consument betere informatie krijgt, zodat die beter weet waar het geproduceerde rundvlees vandaan komt en aan welke duurzaamheidseisen het voldoet. Op basis van die eerlijke en transparante voorlichting koopt de burger-consument vervolgens meer rundvlees. De rol van de burger-consument blijft bij beide geïnterviewden beperkt tot het bewuster kiezen en kopen van rundvlees dat aan dat nieuwe keurmerk voldoet. Van echte burgerparticipatie is hier dus geen sprake.

Opvallend is dat op dit moment consumenten nog niet of nauwelijks betrokken zijn bij duurzaamheidscertificering door (agrarische) bedrijven en dat dit veel vaker door NGOs wordt gedaan.

Het werken in values-based supply chains (VBSC's) is een mogelijkheid die ook in Nederland perspectief kan bieden. Feenstra and Hardesty (Feenstra and Hardesty 2016) beschrijven Yin's approach (2009) als methode die zij gebruikt hebben voor hun onderzoek en waarbij verschillende VBSC's worden beschreven. Het zou ons inziens waardevol zijn als deze methode ook zou worden 
ingezet om een aantal Nederlandse vlees- of zuivelketens te analyseren en vervolgens ook te toetsen aan de wetenschappelijke literatuur.

\section{Educatie}

Het koppelen van duurzaamheidsthema's binnen de voedselproductie aan een educatieprogramma voor kinderen zou een fraaie ontwikkeling kunnen zijn, zoals ook wordt gesuggereerd door de auteurs Feenstra en Hardesty.

Naast vroegtijdige educatie over voedsel en de duurzaamheid van het productieproces is het wenselijk om te werken aan integrale methoden om duurzaamheid te meten en tevens de burgerconsument bewust te maken van de grote nuances die hierin zitten.

Want wanneer je maatregelen in het totale voedselsysteem (tegenwoordig vaak de kringloop genoemd) beoordeelt op hun duurzaamheid, vraagt dat om radicale nuance. Hoe graag we het ook willen, een schijnbaar eenvoudige maatregel heeft namelijk in de complexe voedselkringloop eigenlijk nooit een simpele uitwerking.

Duurzaamheidsinstrumenten/garantiesystemen kunnen helpen om aan duurzaamheidsdoelen te werken en het gesprek tussen verschillende partijen (agrarische sector, overheden, NGOs en burgers/consumenten) te voeren. Een eerste stap zou kunnen zijn om per keten een consumentenpanel te vormen om zo mee te kunnen discussiëren over de definities van duurzaamheid. 


\section{$1 \quad$ Inleiding}

Het vertrouwen van consumenten in de wijze waarop producenten werken is de afgelopen decennia aan grote veranderingen onderhevig. In het verleden werden bedrijven vaak vanzelfsprekend vertrouwd. De affaire met het afzinken van een olieopslaginstallatie (Brent Spar) en de discussie tussen Shell en Greenpeace in 1995/1996 leidde in dat kader tot een echte trendbreuk: burgers en consumenten eisen sindsdien van bedrijven dat zij zich verantwoordelijk gedragen en dat doen volgens bepaalde standaarden (Meerburg 2004). Nog beter zouden zij het vinden als zij direct bij de managementbeslissingen betrokken zouden worden, zo betoogt dezelfde auteur. Daarbij komt dat burgers steeds hoger opgeleid en beter geïnformeerd zijn, waardoor de roep om controle verder toeneemt (Chopyak and Levesque 2002). De vrije beschikbaarheid van informatie op het internet vormt voor de consument een extra mogelijkheid om zich te informeren over de productiemethoden die bedrijven hanteren. Daarbij dient uiteraard wel te worden aangetekend dat informatie die op internet staat helaas niet altijd betrouwbaar is.

De eisen vanuit burgers en consumenten betroffen in eerste instantie vooral multinationals. Dit is de afgelopen decennia verder uitgebreid tot het midden- en kleinbedrijf: ook in de agri- \& foodsector. Bedrijven zijn zich bewust van dit eisenpakket en spelen daar regelmatig op in door gebruik te maken van 'corporate governance'. Dit concept omvat de manier waarop het management van een onderneming aankijkt tegen de eigen organisatie, haar bestaansrecht en haar functioneren tracht te onderbouwen zowel richting de aandeelhouders ('shareholders') als stakeholders. Hiermee wordt de 'license to operate' verder versterkt.

Burgers en consumenten eisen dat bedrijven laten zien dat zij aandacht besteden aan het belang van toekomstige generaties door hun economische, ecologische en sociaalmaatschappelijke impact te meten en zich te gedragen volgens bepaalde morele standaarden (Meerburg 2004). Natuurlijk kunnen ook bedrijven ethische dilemma's vaak niet oplossen, maar zij kunnen wel hun worsteling hierin aangeven en daarover communiceren.

Een belangrijke vraag is wat ondernemingen ermee opschieten als zij voldoen aan de maatschappelijke eisen. Keijzers en Jeurissen hebben deze vraag beantwoord: 1. bedrijven die zich gedragen volgens de normen die wet- en regelgeving stellen hebben minder problemen met duurzaamheidsvraagstukken; 2. De markt kan 'goed' gedrag belonen en 'slecht' gedrag afstraffen; en 3. bedrijven accepteren het vrijwillig als verplichting omdat zij het als een integraal deel van hun bedrijfsvoering beschouwen (Keijzers and Jeurissen 2002).

Ethisch handelen van bedrijven is volgens Siebens (Siebens 2002) op verschillende manieren te realiseren: 1 . Door zelfregulering, 2 . Door transparantie en verantwoordelijkheid uit te stralen in de communicatie, 3. Door gebruik te maken van de 'best practices' en normatieve aanbevelingen, 4 . Door het inzetten van een panel die de bedrijfsacties beoordelen, en 5 . Door zich te houden aan de vigerende wetgeving.

Vervolgens is het van belang op welke manier bedrijven dit ethisch handelen in hun bedrijfsvoering implementeren. Een van de manieren waarop ze dat kunnen doen is door gebruik te maken van garantiesystemen en duurzaamheidsinstrumenten, zoals keurmerken, standaarden en certificatieschema's. Deze instrumenten beoordelen of meten duurzaamheid op de een of andere wijze, bijvoorbeeld via rekentools of certificaten.

In de afgelopen jaren is er in de agri-food sector een breed scala aan keurmerken ontwikkeld gebaseerd op diverse aspecten van duurzaamheid. Denk bijvoorbeeld aan PlanetProof, of het Beter Leven Keurmerk van de Dierenbescherming. Er is echter behoefte aan een integraal overzicht van duurzaamheidseffecten van veehouderijsystemen, waarbij de verschillende deelaspecten worden gecombineerd. Daarnaast zijn er keuzes die een producent kan maken binnen de agrarische productie, 
bijvoorbeeld keuzes in rassen of herkomst van dieren. Er is nog onvoldoende wetenschappelijk inzicht in de verschillen in duurzaamheid tussen deze keuzes. Dat betekent dat deels informatie over duurzaamheid ontbreekt en dat er anderzijds conflicterende duurzaamheidsaspecten zijn. Om goed en helder te communiceren is daarom een integratieslag nodig om de verschillende perspectieven op duurzaamheid meer te integreren. Keurmerken zijn belangrijk als communicatiemiddel naar afnemers en consumenten. Ze zijn daarmee ook belangrijk voor verdienmodellen en economisch draagvlak voor verduurzaming, ook binnen de veehouderij. De rundveehouderij heeft specifiek behoefte aan een meer integrale benadering om zo de bijdrage aan natuur, landschap en biodiversiteit te kunnen integreren in communicatie van rundvleesveehouders naar de consument. In hoeverre dat verwerkt kan of moet worden in een keurmerk is een belangrijke vraag.

Dit onderzoek bekijkt de rol, wensen en de invloed van de consument op keurmerken bij voedselproductie, specifiek binnen de rundveehouderij. Er vindt een verkenning plaats op welke manieren de rol van de consument kan worden versterkt bijvoorbeeld door burgerparticipatie, online beoordelingsplatform, participatieve monitoring, betrokkenheid van bepaalde non-gouvernementele organisaties (NGO's), etc. De hoofdvragen zijn de volgende:

1) Hoe kan de consument betrokken worden in de beoordeling/verbetering van duurzaamheidskeurmerken?

2) Hoe kan de consument betrokken worden bij het meten van duurzaamheid? 


\section{Werkwijze}

De verkenning vond plaats door een uitgebreide literatuurstudie en twee interviews, waarmee werd getracht deze hoofdvragen te beantwoorden. De methodieken hiervoor staan hieronder beschreven.

Na de inventarisatie van de wetenschappelijke literatuur zijn aanvullend twee semi-gestructureerde interviews gehouden met in het onderzoek participerende rundveehouders. Deze veehouders genieten landelijke bekendheid, onder meer door het winnen van innovatieprijzen en zijn regelmatig in de media te vinden. Zij zijn met hun bedrijfsconcept innovatiever dan de gemiddelde veehouder en hebben dus een visionaire kijk op duurzaamheid.

De gespreksthema's en vragen die gesteld zijn, kwamen tot stand door de bevindingen uit de literatuur en de dagelijkse praktijk in Nederland, zoals de betrokken onderzoekers die kennen, met elkaar te vergelijken en de geïnterviewden te bevragen op wat zij willen met betrekking tot duurzaamheidscertificering en of zij daarin een rol voor de burger zien. Hen is ook gevraagd hoe de participatie van burgers bij de verduurzaming van de rundvleesketen er volgens hen uit zou moeten gaan zien.

De thema's, vragen die ten grondslag liggen aan het semi-gestructureerde interview zijn bijgevoegd als bijlage 1 . Door gebruik te maken van Appreciative Inquiry (AI) als procesmethodologie (Cooperrider and Whitney 2002) zijn het verhaal en de ervaringen van de geïnterviewde leidend geweest voor het verloop van interview en zijn de thema's en vragen op een zo passend mogelijke wijze ingevoegd.

De interviews zijn in november 2020 afgenomen en duurden beiden ongeveer 1 uur. Na transcriptie en analyse zijn de belangrijkste punten op een rij gezet en enkele relevante en illustratieve quotes geselecteerd. 
We gaan in dit hoofdstuk eerst, op basis van gevonden internationale literatuur, nader in op voedselsystemen en de rol van korte ketens. Vervolgens kijken we naar de mogelijkheden die verschillende duurzaamheidsinstrumenten kunnen bieden. Ook onderzoeken we de rol van de consument/burger hierbij en kijken we naar mogelijke alternatieve garantiesystemen. Tot slot kijken we naar de voor- en nadelen van het labelen van voedsel.

\subsection{Voedselsystemen}

Allereerst is het belangrijk om je te realiseren dat het voedsel dat we elke dag eten tot stand kan komen door de processen en praktijken van veel verschillende actoren. De Food \& Agricultural Organization of the United Nations (FAO, 2018) hanteert voor voedselsystemen de volgende brede definitie: "The entire range of actors and their interlinked value-adding activities involved in the production, aggregation, processing, distribution, consumption and disposal of food products [...] and parts of the broader economic, societal and natural environments in which they are embedded."

Een opvallende constatering is natuurlijk dat het dominante voedselsysteem zoals dat na de Tweede Wereldoorlog is ontstaan de afgelopen paar decennia meer en meer complex geworden is. Dit heeft geleid tot heel veel uitdagingen, zowel op sociaal als milieutechnisch vlak. Veel onderzoekers hebben de uitdagingen beschreven, zoals bodemuitputting, klimaatverandering, onder- en overvoeding, land grabbing, etc. (Lindgren et al. 2018; Scholes et al. 2018). De belangrijkste systeemfouten van het dominante voedselsysteem worden bijvoorbeeld beschreven door Kennedy en Liljeblad (Kennedy and Liljeblad 2016).

Voedsel(on)zekerheid is vaak de basis van de problematiek, waarbij vervolgens fysische, economische en sociale grenzen als belangrijke thema's zijn geïdentificeerd (Kennedy and Liljeblad 2016). Pimbert (Pimbert 2012) beschrijft het gebrek aan democratische ontwikkeling en exclusie binnen voedselsystemen als een belangrijk probleem en roept op tot een meer inclusief voedselsysteem waar consumenten de ruimte krijgen om te participeren. Deze participatie kan eigenlijk op meerdere wijzen plaatsvinden. Aan de ene kant kan een consument passief participeren, en dat doen door producten te kopen die zijn geproduceerd in een voedselsysteem dat aansluit bij zijn/haar gedachtegoed. Deze aansluiting kan al dan niet zijn geborgd via de inzet van duurzaamheidsinstrumenten. Aan de andere kant kan een consument actief participeren, dan kom je meer terecht in de 'community supported agriculture' initiatieven, kortweg CSA $^{1}$ genoemd. In deze alternatieve voedselsystemen, waarin vaak een korte ketenbenadering de basis is, delen producenten en consumenten de verantwoordelijkheid en streven ze naar een eerlijkere beprijzing. De industrie en retail is dan in feite tussen de producent en consument uitgehaald.

Kneafsey et al. (Kneafsey et al. 2013) definieert deze korte keten als volgt: "A long term partnership between one or several producers and their consumers where consumers are associated to a more or less large extent with the producers' decisions and labour."

Een dergelijke CSA-benadering kan verschillende vormen hebben en hebben vaak de ambitie om te voorzien in voedsel vanuit een basis van gemeenschappelijke waarden. In Nederland zien we dit soort CSA-systemen zich meer en meer ontwikkelen in urbane en semi-urbane gebieden (De Schutter et al., 2018). Belangrijk is dat er een directe relatie bestaat tussen de producent(en) en consumenten: consumenten dragen financieel bij aan de agrarische bedrijfsvoering en krijgen in ruil daarvoor een

\footnotetext{
${ }^{1}$ De afkorting CSA wordt ook regelmatig gebruikt voor Climate-Smart Agriculture. Hier gaat het dus om een andere afkorting.
} 
deel van de oogst. Hiermee vindt ook direct een deel van de risicospreiding plaats: als de oogst minder goed is, wordt het verlies ook gedeeld door de consumenten (Paul 2019). Dit zorgt ervoor dat ook boeren die op een kleinere schaal willen werken en op andere wijze dan in het dominante voedselsysteem, toch een manier hebben om in hun levensonderhoud te voorzien (Blättel-Mink et al. 2017). Je zou kunnen zeggen dat een CSA-bedrijf dus meer produceert dan alleen een product.

\subsection{Duurzaamheidsinstrumenten}

Passieve betrokkenheid van consumenten bij de vormgeving van het voedselsysteem kan worden gestimuleerd door de inzet van duurzaamheidsinstrumenten. Met duurzaamheidsinstrumenten doelen we in dit rapport op instrumenten die bedrijven kunnen gebruiken om hun duurzaamheidsprestaties inzichtelijk te maken. Dit kunnen bijvoorbeeld keurmerken, standaarden of certificatieschema's zijn. Passieve betrokkenheid wil zeggen dat een consument geen actieve inbreng bij de vormgeving van het voedselsysteem heeft, maar dit bijvoorbeeld overlaat aan certificerende instellingen of NGO's.

Ondernemers in de agrifood-sector besluiten tot de inzet van duurzaamheidsinstrumenten op twee mogelijke gronden: a.) ze hopen er economisch voordeel uit te krijgen, en/of b.) ze zijn gecharmeerd van duurzame productie en proberen de impact van hun bedrijf op bepaalde terreinen te veranderen. In de volgende paragraaf wordt nader ingegaan hoe bedrijven besluiten tot inzet van bepaalde duurzaamheidsinstrumenten.

\subsubsection{Selectie van duurzaamheidsinstrumenten}

De studie van Rueda et al. (Rueda et al. 2017) laat zien welke instrumenten agri-food bedrijven adopteren om duurzaamheid in hun leveringsketen te promoten en hoe ze keuzes maken in die duurzaamheidsinstrumenten. Zij illustreren dit aan de hand van een beslisboom die bedrijven hanteren voor de selectie van duurzaamheidsinstrumenten (Rueda et al. 2017). Elk besluit dat een agri-food bedrijf met betrekking tot duurzaamheid neemt, begint met het inschatten van het risico voor het milieu. Alleen bij een hoog risico is er een stimulans om de volgende stap te zetten en die bestaat uit het achterhalen van het bewustzijn van de consumenten en burgers met betrekking tot het probleem. Pas wanneer er voldoende maatschappelijke urgentie is, gaat een bedrijf over tot de actie om te achterhalen of er duurzamere technologieën voor een voor haar shareholders (aandeelhouders) redelijke prijs beschikbaar zijn. Uit alle daarop volgende afwegingen blijkt uiteindelijk welk duurzaamheidsinstrument qua prijs-kwaliteit het meest geschikt is. Bij weinig controle over de leveringsketen bepaalt de merkherkenning of een agri-food bedrijf kiest voor een instrument met of zonder communicatie, dan wel betrokkenheid van de consument. Bij een hoge mate van controle over de leveringsketen en wanneer het product niet op een specifieke plaats gemaakt wordt, valt de keuze op strikte standaarden met certificering door derde partijen.

\subsubsection{Duurzaamheidscertificering door derde partijen}

Het gebruik van standaarden met certificering is een van de meest breed gepromote instrumenten voor duurzame agrarische ontwikkeling (Loconto and Hatanaka 2018). Het governance model dat voor deze standaarden gebruikt wordt, volgt een typische structuur: onafhankelijke standaard-ontwikkeling organisaties creëren de duurzaamheidsstandaarden en geaccrediteerde derde partij certificeerders zorgen voor naleving van de standaarden door de leveranciers (Fouilleux and Loconto 2017; Loconto 2017; Loconto and Busch 2010; Loconto and Hatanaka 2018). De legitimatie van de uitkomst van deze structuur is een inbedding van standaarden en audits volgens de wetenschappelijke normen van objectiviteit, repliceerbaarheid en geldigheid (Loconto 2017; Lytton 2014; Porter and Van der Linde 1995; Power 1997). Niettemin hebben zowel mensen uit de praktijk als wetenschappers kritiek op deze derde partij governance. Het derde partij certificeringsmodel (TPC) is 1) vanwege het type kennis - wetenschappelijke en expertkennis- dat gebruikt wordt niet waardenvrij en niet neutraal (Bain and 
Hatanaka 2010; Busch 2011; Hatanaka 2010a; Hatanaka 2010b; Loconto and Hatanaka 2018; Ransom et al. 2017), daarnaast 2) zijn de kwantitatieve en uniforme indicatoren niet in staat de complexiteit van objecten en gevolgde praktijken vast te leggen (Hatanaka 2010b; Loconto 2014; Loconto 2015; Loconto and Hatanaka 2018; Raban 2010) en 3) de TPC praktijken zijn een black box en niet openbaar te controleren en roepen daardoor vragen op met betrekking tot de democratische verantwoording (Busch 2011; Loconto and Hatanaka 2018; Ponte and Cheyns 2013).

Certificering van duurzaamheid heeft nog andere gevolgen dan moeilijke controleerbaarheid door het algemene publiek. Bush et al. (Bush et al. 2013) tonen op basis van het voorbeeld van MSC certificering in de visserij aan dat hoe geloofwaardig een transparant, verantwoordelijk en wetenschappelijk onderbouwde certificering door een derde partij ook kan zijn, deze toch te ondermijnen is, doordat ten eerste zich nog ontwikkelende organisaties niet aan kunnen sluiten, omdat ze niet kunnen voldoen aan de certificeringseisen en ten tweede organisaties die zich verder willen verbeteren daar ook geen mogelijkheden toe hebben. Zij noemen dit een duivelse driehoek waarbij het balanceren is tussen geloofwaardigheid, toegankelijkheid en continue verbetering. Als mogelijke oplossing noemen ze een gelaagd certificeringssysteem waardoor diversificatie mogelijk wordt. Een voorbeeld van zo'n gelaagd certificeringssysteem is het Beter Leven Keurmerk waarbij 1 tot 3 sterren te behalen zijn. Dit keurmerk richt zich echter alleen op het verbeteren van dierenwelzijn en is (nog) geen integraal duurzaamheidskeurmerk, hoewel wel wordt verkend of milieucomponenten in de toekomst kunnen worden toegevoegd.

\subsection{Betrokkenheid consument bij garantiesystemen voor duurzaamheid}

Rueda et al. (Rueda et al. 2017) noemden de invloed van het bewustzijn van consumenten en burgers op de besluitvorming van agri-food bedrijven met betrekking tot duurzaamheidsinstrumenten: vooral op het moment dat consumenten bekend zijn met het productieproces van een bedrijf en de invloed daarvan op het milieu, is het voor bedrijven een competitief voordeel als ze overgaan tot toepassing van een garantieschema. Dit laat zien hoe belangrijk het is dat consumenten zich bewust en goed geïnformeerd zijn over de gevolgen van hun consumptie en productiemethoden (De Olde et al. 2020; Kijlstra et al. 2009; Vaarst et al. 2015).

Doordat consumenten steeds minder verbonden zijn met het voedselproductiesysteem, raken ze in toenemende mate gescheiden van de gevolgen die hun dieet keuzes hebben (Davis et al. 2016; De Olde et al. 2020). Om consumenten goed geïnformeerd keuzes te laten maken, is transparantie vanuit de gehele voedselketen vereist (De Olde et al. 2020; Kok et al. 2020; Vaarst et al. 2015). De veel voorgestelde oplossing van certificeringsschema's en labels kunnen veel informatie verschaffen, maar behandelen vaak één aspect van duurzaamheid. Certificeringsschema's roepen tegelijkertijd vragen op met betrekking tot de geloofwaardigheid, geldigheid, implementatie, transparantie en machtsrelaties (Boström et al. 2015; De Olde et al. 2020; De Olde et al. 2018; Lundmark et al. 2018). Duurzaamheid vraagt om transparantie en verantwoordelijkheid in de gehele keten (De Olde et al. 2020). Overigens is het een illusie om te denken dat alle segmenten consumenten hieraan waarde hechten. Een prijskoper zal minder in productiewijze geïnteresseerd zijn dan een kritische consument. Toch is het belangrijk dat de rapportage over maatschappelijke eisen vanuit bedrijven aansluit op de heterogene wensen van de verschillende groepen consumenten en hun algemene vraag naar meer transparantie (Meerburg 2004).

\subsubsection{Burgerparticipatie}

Burgerparticipatie is een middel om besluitvormingsprocessen van bedrijven te verbeteren. Volgens sommige auteurs creëert burgerparticipatie bewustzijn over duurzaamheidsproblemen en helpt de acceptatie en betrokkenheid te vergroten met betrekking tot voorgenomen plannen (Bush et al. 2005). Er zijn echter verschillende niveaus van betrokkenheid om bedrijven te motiveren hun processen te verduurzamen. Deze zijn door Arnstein benoemd in de zogenaamde burgerparticipatieladder (Arnstein 1969). De ladder voor burgerparticipatie is in de loop der jaren op 
verschillende manieren aangepast door andere onderzoekers. Bush et al. (Bush et al. 2005) maken bijvoorbeeld in hun studie gebruik van zo'n aangepaste versie en kiezen daarbij voor de drie onderdelen die voor hun onderzoek het belangrijkste zijn, namelijk informatievoorziening, consultatie en actieve betrokkenheid van burgers in besluitvormingsprocessen.

Positieve veranderingen zijn gemakkelijker op gang te brengen wanneer houdingen, overtuigingen of voorkeuren van de mensen die de middelen managen of er van afhankelijk zijn meegewogen worden in de identificatie van de problemen en het ontwikkelen van oplossingen (Lynam et al. 2007; Ramirez 1999). Een grotere betrokkenheid van de gemeenschap zorgt voor meer begrip en vertrouwen (Lynam et al. 2007). Om de lokale opvattingen en perspectieven erbij te betrekken, zijn er verschillende benaderingen die in drie klassen verdelen te zijn (Lynam et al. 2007):

1) diagnostische en informerende methoden om kennis, waarden of voorkeuren aan een doelgroep te onttrekken om lokale issues beter te begrijpen en ze te betrekken bij het besluitvormingsproces;

2) co-lerende methodes waarbij de perspectieven van alle groepen veranderen als resultaat van het proces, maar de gegenereerde kennis aan het besluitvormingsproces wordt geleverd;

3) co-management methodes waarbij alle betrokken actoren leren en bij het besluitvormingsproces betrokken worden.

Participatieve instrumenten moeten verder (Lynam et al. 2007):

1) communicatie en leren ondersteunen tussen de insiders en buitenstaanders die de instrumenten gebruiken

2) aanpasbaar zijn voor implementatie in verschillende besluitvormingscontexten en voor gebruik door verschillende gebruikers, ook op lokaal niveau en

3) data en informatie produceren die bruikbaar en geldig is als basis voor besluitvorming of gebruikt kan worden voor verdere analyses.

\subsubsection{Betrokkenheid consument bij duurzaamheidscertificering door derde partijen}

In de beslisboom van Rueda et al. (Rueda et al. 2017) is te zien dat consumenten niet of nauwelijks betrokken zijn bij duurzaamheidscertificering door derde partijen. Echter, een certificeringspartij als ISO laat vanuit een comité voor consumentenbeleid (ISO COPOLCO, 2011) zien waarom consumenten wel bij het ontwikkelen van een certificeringssysteem door derde partijen betrokken zouden moeten zijn en hoe dat te doen. Standaarden die eveneens gebaseerd zijn op de belangen en wensen van consumenten zijn namelijk relevanter voor de markt, verbeteren het consumentvertrouwen in de producten en maken verspreiding ervan op de markt gemakkelijker. Consumenten moeten daarom bewust worden gemaakt van het belang van standaarden en hun participatie bij de ontwikkeling ervan. Ze zouden baat kunnen hebben bij training in procedures betreffende standaarden en effectieve participatie. Daarnaast hebben consumenten (financiële) ondersteuning nodig om deel te kunnen nemen (ISO COPOLCO, 2011)(Sitnikov and Bocean 2012).

\subsubsection{Voedseldemocratie}

Lang (2005) introduceert het concept Voedseldemocratie in reactie op de toenemende bedrijfscontrole van en het gebrek aan deelname van consumenten in het dominante voedselsysteem. Hij bepleit de noodzaak van het democratiseren van het voedselsysteem en te kijken naar 'voedsel als een plaats van een democratisch proces', wat in essentie een oproep is om de rol van burgers in het management en controle van het voedselsysteem te verbeteren (Renting et al. 2012) (Lang 1998). Initiatieven waarbij de burgers-consumenten direct betrokken zijn bij de voedselproductie activiteiten laten een verschuiving zien in de rol van consumenten van passieve eindgebruikers en vooral kopers van voedselproducten naar pro-actieve burger-consumenten (Johnston 2008; Renting et al. 2012; Soper 2007); die van plan zijn de controle over hoe voedsel wordt geproduceerd en geleverd, te herwinnen (Renting et al. 2012). Tegelijkertijd, echter, betekenen initiatieven vaak een cruciale 
verschuiving aan de producentkant - van landbouw als alleen het verkopen van grondstoffen aan de voedselindustrie tot een activiteit die verschillende elementen van voedselvoorziening herwaardeert en opnieuw inlijft met een bredere sociale en politieke betekenis (Renting et al. 2012).

Expressies van 'voedselburgerschap' hervormen de relaties tussen zowel de voedselpraktijken en de markt als met publieke instellingen op manieren die verder gaan dan materiële en economische uitwisseling en die bijdragen aan 'moralisatie' (of zelfs civilisatie) van voedseleconomieën (Renting et al. 2012).

Dezelfde auteurs geven ook een theoretische reflectie op civic food networks (CFNs) waarin consumenten in toenemende mate een producerende rol aannemen en de identiteitsverschillen tussen consumenten en producenten verdwijnen (Renting et al. 2012). Het concept pro-sumption van Toffler (Toffler 1980) geeft enige inzichten en geeft aan dat in een post-industriële maatschappij het onderscheid tussen productie en consumptie steeds vager wordt. Zwick et al. (Zwick et al. 2008) bediscussiëren aan de hand van het pro-sumption concept dat de werving van consumenten in productieve co-creatie relaties leunt op het meegaan in de consumentenbehoeften met betrekking tot erkenning, vrijheid en keuzevrijheid. Renting et al. (Renting et al. 2012) gebruiken de term prosumption om te verwijzen naar de actieve betrokkenheid van consumenten in voedselproductie als een opzettelijke keuze om hun keuzevrijheid te vergroten en betrokkenheid bij het agrovoedselsysteem. De achterliggende motivaties om dit te doen kunnen verschillen: soms verbinden consumenten hun betrokkenheid met het idee van een gezonder dieet, wat past in de huidige voedseltrends (Hanson et al. 2019), soms is het een manier voor consumenten om hun betrokkenheid bij boeren of een bepaalde manier van voedselproductie vorm te geven (Adam 2006). Natuurlijk vormen uiteindelijk ook de geproduceerde producten een belangrijke motivatie voor de consumenten (Vasquez et al. 2017).

Actieve participatie van consumenten heeft geleid tot de opkomst van veel CSA-initiatieven, ook in Nederland. Het concept van de Herenboeren is hiervan een mooi voorbeeld. Er moet wel worden aangegeven dat, afhankelijk van het type partnerschap dat bestaat, de waarden en motivatie van stakeholders om actief te zijn binnen en deel uit te maken van een bepaald CSA-initiatief kunnen variëren (Pettenati et al. 2018). Het is daarom belangrijk om steeds de variatie in persoonlijke opvattingen en economische, sociale en milieutechnische waarden in ogenschouw te nemen, zoals aangegeven is in de studie van (Perényi et al. 2016). Deze auteurs geven tevens aan dat het netwerk dat wordt opgebouwd doordat consumenten samen verantwoordelijk zijn voor het bedrijf, ook emotionele meerwaarde voor hen biedt omdat ze mensen met dezelfde morele waarden ontmoeten. Dit aspect wordt ook door anderen onderschreven (Cox et al. 2008).

CSA's vormen ook een manier voor boeren en consumenten om de economische uitdagingen met betrekking tot voedsel te verkleinen. Doordat de retail er als het ware tussenuit wordt gehaald, krijgen consumenten toegang tot goedkopere producten, veelal van biologische oorsprong (Henderson and Van En 2007) en kan de boer een hogere prijs verdienen. Doordat het voedselaanbod gestabiliseerd wordt, kan de consument producten voor een vaste prijs inkopen. De boer heeft vervolgens een stabieler inkomen en een kleiner productrisico. In sommige gevallen neemt ook de concurrentie voor de boer af (Peuker 2018).

\subsection{Alternatieve en participatieve garantiesystemen}

\subsubsection{Interne controlesystemen (ICS) en participatieve garantiesystemen (PGS)}

Sacchi (Sacchi 2019) beschrijft hoe de laatste jaren parallel aan de groei van alternatieve agri-food netwerken de belangstelling voor en adoptie van alternatieve en participatieve praktijken, gewijd aan het garanderen van de authenticiteit van biologische producten, eveneens is gegroeid. Die praktijken bestaan uit interne controle systemen oftewel groepscertificering (ICS) en participatieve garantiesystemen (PGS). ICS is een kwaliteitsgarantiesysteem voor groepen van kleine boeren waarbij een derde partij certificeerder alleen het goed functioneren van het systeem als geheel inspecteert. PGS zijn lokaal gerichte kwaliteitssystemen die (biologische) producenten garanderen gebaseerd op 
actieve deelname van stakeholders en zijn gebouwd op een fundering van vertrouwen, sociale netwerken en kennis uitwisseling (IFOAM, 2003; Sacchi, 2019). Sacchi beschrijft PGS als lokaal gebaseerde praktijken om de authenticiteit van biologische producten te garanderen en die er voor zorgen dat het een waardevol instrument is voor het krachtiger maken van agrariërs en sociale innovatie (Sacchi 2019). PGS versimpelt bureaucratische procedures voor kleine producenten en verlaagt de kosten door interventies van certificerende partijen te vermijden (Sacchi 2019). Loconto en Hatanaka (Loconto and Hatanaka 2018) zeggen dat dergelijke participatieve garantie systemen (PGS) vanwege het verleggen van de autoriteit van wetenschappers naar multi-stakeholder groepen een levensvatbaar alternatieve vorm van certificering voor biologische standaarden zijn geworden.

Hoe werkt dit in de praktijk? Als voorbeeld nemen we Demeter, het kwaliteitskeurmerk voor biodynamische landbouw en voeding, dat een vorm van collegiale toetsing (C T) kent. Sinds 2005 wordt door hen hiermee geëxperimenteerd, oorspronkelijk onder de naam Mansveltscore. Elke boer kijkt met collega's naar de kwaliteit van het bedrijf aan de hand van de Demeter-richtlijnen en de mogelijke verbeterpunten die hij of zij kan toepassen op het bedrijf. Volgens de Stichting Demeter is het enthousiasme onder de deelnemende boeren groot. Deelname aan collegiale toetsing is weliswaar verplicht, maar de resultaten worden niet betrokken bij het afgeven van licenties, juist om zoveel mogelijk open discussies te stimuleren. Voor het verkrijgen van een licentie blijven de reguliere inspecties bestaan. C T is echt een ontwikkelingsinstrument. De bedrijfsontwikkeling gebeurt op basis van vrije keuzes door de boer, maar de systematiek dient te garanderen dat de voornemens worden gerealiseerd. Dus de boer bepaalt als het ware wat er gebeurt en Stichting Demeter garandeert dàt het gebeurt. Wellicht is het mogelijk om deze vorm binnen Demeter uit te breiden door consumenten bij de toetsing te betrekken, dan ontstaat een vorm van participatieve landbouw.

\subsubsection{Rol relaties en bemiddelingsbronnen in verduurzaming voedselketens}

Chiffoleau et al. (2016) hebben onderzoek gedaan naar de condities waaronder lokale voedselketens in stedelijke voedselsystemen een evolutie te weeg kunnen brengen in de praktijken en kennis van 'gewone' actoren richting een meer duurzame landbouw. De 'gewone' actoren zijn actoren zonder of met beperkte vaardigheden in landbouw en/of bewustzijn van duurzaamheid. Chiffoleau et al. (Chiffoleau et al. 2016) baseren hun onderzoek op de economische sociologie theorie die zegt dat economische activiteiten ingebed zijn in sociale structuren (Chiffoleau et al. 2016; Swedberg and Granovetter 2001). Zij tonen ook aan hoe interpersoonlijke relaties een bron zijn van nieuwe kennis, die het mogelijk maakt actoren met weinig of geen bewustzijn van agrarische en/of duurzaamheidsthema's anders te laten denken en handelen. Deze auteurs laten ook zien hoe een labelsysteem een essentiële rol speelt zowel als intermediair object en als bemiddelingsbron. Het is een bron van nieuwe kennis en nieuwe relaties tussen stakeholders. Het labelsysteem met 3 kleuren (groen, oranje, paars) is toegankelijk en ondersteunt twee belangrijke principes: transparantie en participatie (Chiffoleau et al. 2016). Chiffoleau et al. (2016) concluderen tevens dat zowel relaties als bemiddelingsbronnen bewezen relevante kenmerken zijn in het proces van transitie naar meer duurzame praktijken in een stedelijk voedselsysteem zoals zij dat hebben onderzocht.

\subsubsection{Review marketing - Word of mouth (WOM)}

Om de houding tot een product te beïnvloeden is communicatie tussen consumenten (mond-tot-mond oftewel WOM) een heel krachtig instrument (Brown and Reingen 1987; Herr et al. 1991; Schlosser 2011; Sultan et al. 1990). Via het internet kunnen consumenten hun mening geven over producten of diensten in de vorm van beoordelingen en argumenten; een noodzakelijk kenmerk van website om consumenten te lokken en behouden (Schlosser 2011). Bijna 98\% van alle online kopers rapporteert dat ze eerst de beoordelingen van andere consumenten lezen voor ze een aankoop doen (Freedman and Jin 2008; Schlosser 2011). Daarvoor is het nodig dat de bezoekers van website beoordelingen geven die de consumenten helpen en overhalen om te kopen (Schlosser 2011). Of consumenten een beoordeling door collega consumenten helpend of overtuigend vinden, hangt af van de extremiteit van de kwantitatieve beoordeling (in aantal sterren) en of de bijbehorende argumenten (kwalitatieve beoordeling) alleen voordelen of zowel voor- als nadelen bespreekt. Bijvoorbeeld een hoge 
beoordeling (veel sterren) met een argumentatie waarin zowel voor- als nadelen worden genoemd, maakt de totale beoordeling ongeloofwaardig, omdat de beoordeling en argumentatie niet consistent zijn. De consument betwijfelt of de collega consument die de beoordeling heeft gegeven wel in staat is om de waarheid te vertellen. In zo'n geval kunnen beter alleen positieve argumenten worden genoemd. Hoe consistenter iemands argumenten zijn in vergelijking met hun houdingen, des te bekwamer en des te helpender en overtuigender schijnt iemand te zijn (Schlosser 2011). Wanneer het sociale en financiële risico groter is, zullen consumenten voorzichtiger zijn met het geven van beoordelingen. Aan de andere kant zullen consumenten bij een hoog - vooral sociaal - risico eerder de statistieken geloven dan dat ze zich laten beïnvloeden door een of andere beoordeling (Schlosser 2011).

Vanwege de psychologische effecten die een rol spelen bij de beoordeling op online platforms en de waarde die aan reviews wordt gehecht, is het nog maar de vraag of een dergelijk online platform waarbij consumenten hun mening kunnen geven over de duurzaamheid van producten een geschikt instrument is om de transitie naar een duurzamer voedselproductiesysteem te bevorderen.

\subsection{Duurzaamheid als waarde}

\subsubsection{Consumententrends}

Tijdens het Symposium Biodiversiteit (Bakker-Smit 2018) merkte Gea Bakker-Smit, Sectormanager Food \& Agri bij Rabobank Nederland, al op dat consumententrends de keten flink veranderen. Deze trends zijn momenteel gemak versus beleving, gezondheid en vitaliteit - lifestyle, meer groenten en minder koolhydraten. Men eet niet meer, maar anders, bijvoorbeeld duurzamer. De groei zit vooral in waarden en niet in volume. Belangrijke waarden zijn smaak, een verhaal en beleving. Mensen willen bijvoorbeeld geen appel, maar een Pink Lady. Andere voorbeelden zijn chocola van Tony Chocolony of de Kromkommer. Supermarkten hebben meer producten met toegevoegde waarden zoals beleving en een goed verhaal nodig.

Transparantie is gevraagd met betrekking tot

- milieu

- gezonder voedsel

- dierenwelzijn

- $\quad$ voedselverspilling (1/3 deel)

De trend volgens Bakker-Smit is de keuze van de consument voor biologisch voedsel. De consument kiest hiervoor omdat het volgens hen gezond (40\%), beter voor het milieu $(39 \%)$ is en vanwege de smaak (37\%), kwaliteit (35\%) en het dierenwelzijn (32\%).

Daarnaast blijkt uit de (internationaal) literatuur dat lokale productie voedsel steeds belangrijker wordt. De drie belangrijkste redenen waarom Amerikaanse consumenten lokaal verbouwd voedsel in supermarkten kopen zijn versheid (83\%), ondersteunen van de lokale economie (68\%) en smaak (53\%) (Feenstra and Hardesty 2016). Daarnaast zijn ze geïnteresseerd in de gevolgen voor het milieu en steunen ze familiebedrijven (Brown 2003; Feenstra and Hardesty 2016). Uit een recent onderzoek in Nederland onder 470 consumenten blijkt dat opleidingsniveau en inkomen belangrijke componenten zijn bij de keuzes voor lokale producten: hoe hoger de opleiding en het inkomen, hoe meer aandacht voor het lokale product en milieu (Moorlag, 2017). Ook geslacht speelt een rol: Nederlandse vrouwen kiezen vaker voor een product dat Nederlandse boeren ondersteunt.

\subsubsection{Op waarden gebaseerde voedselketens}

Consumenten zijn in de Westerse wereld in toenemende mate geïnteresseerd in 'waarden' gekoppeld aan het voedsel dat ze eten en zijn vaker bereid meer te betalen voor voedsel waar een verhaal (story) aan verbonden is dat de boerderij koppelt aan het eten. Daarbij gaat het o.a. over waarden als lokaal geproduceerd zijn, omvang van de boerderij (klein of gemiddeld) of een duurzame productiewijze. Groothandel kanalen die marketing opties bieden die aan deze waarden voldoen, 
worden values-based supply chains (VBSCs) genoemd (Feenstra and Hardesty 2016). Doelen van deze VBSCs zijn: 1) in een grotere economische stabiliteit voor producenten en andere ketenpartners voorzien 2) consumenten voorzien van regionaal voedsel van hoge kwaliteit (Feenstra and Hardesty 2016). De algemene voordelen van VBSCs zijn: transparantie, eerlijke prijzen voor de boeren en het gemak van aankopen van kleine en middelgrote bedrijven. VBSCs worden in toenemende mate gezien als mogelijkheden om strategische business modellen te creëren voor deze bedrijven (Feenstra and Hardesty 2016).

Belangrijkste voordelen van VBSCs voor deelnemende agrariërs zijn: 1) grotere transparantie dan conventionele groothandelkanalen door communicatie van de waarden door de gehele keten om kopers en consumenten te voorzien van de informatie die ze nodig hebben om meer te willen betalen voor de voedselproducten; 2 ) dat ze hogere prijzen opleveren voor de deelnemende agrariërs als gevolg van de strategisch partnerrelaties en het feit dat kopers bereid zijn agrariërs te compenseren voor bepaalde waarden en 3) kopers in deze VBSCs zijn meer bereid om te onderhandelen met agrariërs en nemen vaak een deel van de transactiekosten voor hun rekening en werken met agrariërs samen om voortdurend producten te vinden (Feenstra and Hardesty 2016).

De VBSCs zijn vergelijkbaar met de zogenoemde 'Alternatieve voedselnetwerken' (Sonnino and Marsden 2006a) of 'geneste markten' (Van der Ploeg et al. 2012). Sonnino en Marsden (Sonnino and Marsden 2006b) verklaren dat Alternatieve voedselnetwerken verschillend zijn en losjes gedefinieerd kunnen worden in termen van 'kwaliteit', 'transparantie' en 'lokaliteit' (Feenstra and Hardesty 2016). Uit ander onderzoek (Feenstra et al. 2011) blijkt dat de klanten van VBSCs het verhaal over de boerderij, de schaalgrootte, locatie en hoe het voedsel verbouwd is, willen weten. Daarnaast is het vertellen van een authentiek verhaal vaak belangrijker dan 'lokaal' (Feenstra and Hardesty 2016; Feenstra et al. 2011).

Feenstra and Hardesty (2016) concluderen dat de belangrijkste kwestie is of en hoe VBSCs hun communicatie over hun waarden kunnen verbeteren en de vraag naar op waarden gebaseerde producten kunnen vergroten. Er zijn meer retailers nodig die deelnemen aan VBSCs. Retailers willen echter alleen deelnemen wanneer hun klanten meer naar op waarden gebaseerde producten vragen en bereid zijn om er meer voor te betalen. Daarom is er meer transparantie nodig in de gehele voedselketen. Consumenten zijn zich nog steeds niet bewust van waar hun voedsel vandaan komt of van de waarden die eraan gekoppeld zijn. Ze moeten de reële prijs van voedsel begrijpen. Om dit te bereiken is het volgens Feenstra and Hardesty (Feenstra and Hardesty 2016) nodig om fors in te zetten op het onderwijzen van consumenten, beginnend bij de jeugd, over de verbanden tussen een gezonde omgeving, de economie, gemeenschap en hun eigen gezondheid. Om het begrip voor en de betrokkenheid van het volk bij een meer duurzaam voedselsysteem te vergroten, stellen Feenstra and Hardesty voor om strategische allianties te bouwen en programma's zoals 'Farm to School', 'Farm to Hospital' op te zetten met daarin een strenge evaluatie om de meest effectieve educatiestructuren op lange termijn te kunnen identificeren (Feenstra and Hardesty 2016).

\subsection{Alternatieve garantiesystemen zonder gecontroleerde productgarantie}

\subsubsection{Eigen label}

Naast de alternatieve garantiesystemen zoals groepscertificering (ICS), participatieve garantiesystemen (PGS), values-based supply chains (VBSCs) en review marketing zijn er alternatieve systemen zonder gecontroleerde garantie van producten al dan niet met bedrijfseigen duurzaamheidsclaims.

Het aantal agrariërs dat in Nederland onder een eigen label (farm brand) producten verkoopt, lijkt toe te nemen. Agrariërs maken bij de marketing van hun label gebruik van 'story telling' en een aantal van hen claimt daarbij duurzaamheidsaspecten zonder daarbij aan eisen te voldoen, zoals die voor keurmerken gelden.

Voorbeeld marketingconcept de Zuivelhoeve (www.zuivelhoeve.nl): "Vanuit ons familiebedrijf zorgen we voor eerlijke zuivel." 
De onderliggende vraag is natuurlijk welke definitie van 'eerlijk' men hierbij hanteert en hoe dit geborgd wordt.

De OECD (2016) constateert dat er een toename is van het aantal zelfbedachte milieuclaims. Contact met consumenten bestaat uit rechtstreeks contact in de winkel, websites, facebook pagina's, blogs, nieuwsbrieven. Burgers-consumenten lijken op basis van het verhaal en de relatie die ze met de agrariër hebben vertrouwen te hebben in de producten. Er zijn consumenten die kritische vragen stellen, maar die kunnen in veel gevallen door onvoldoende kennis van de consument gemakkelijk worden weerlegd.

Producten die melk- en rundveehouders verkopen zijn vlees(pakketten), kaas en andere zuivelproducten. Ook de melktap voor de verkoop van rauwe melk is de laatste jaren in opkomst. Tijdens de coronacrisis geven agrariërs met directe verkoop aan dat het aantal klanten sterk toegenomen is. Consumenten denken volgens hen namelijk dat rauwe melk gezonder is en de weerstand verbetert of zelfs beschermd tegen Covid-19, een gedachte waarvoor geen wetenschappelijk bewijs is (Costerus 2020).

Hoewel het aan de ene kant toe te juichen is dat agrariërs een directe relatie met de burgerconsument hebben en hun producten voor een hogere prijs weten te verkopen, kan het verkopen op basis van alleen een goed verhaal ook nadelen hebben. Zo hoeven agrariërs die zonder keurmerk onder eigen label alles wat ze produceren rechtstreeks aan de consument verkopen niet te voldoen aan duurzaamheidseisen waar de mainstream wel aan moet voldoen. Zij moeten overigens wel voldoen aan de hygiëne-eisen voor huisverkoop waarop de NVWA controleert, maar vaak is onduidelijk aan welke veiligheidseisen verder moet worden voldaan. Bij de rauwe melktap bijvoorbeeld tapt de burger zijn of haar product zelf en staat aangegeven wat de mogelijke risico's van het drinken van rauwe melk zijn. Maar aanvullend is het de vraag of en zo ja, hoe, er überhaupt wordt gecontroleerd op kwaliteit. Hoe zit het bijvoorbeeld met het niveau van residuen (antibiotica, hormonen, dioxinen, etc.), zuiverheid van het product (bijvoorbeeld de hoeveelheid aan de melk toegevoegd water) of het aantal kiemen in bijvoorbeeld vleesproducten die rechtstreeks van de boer aan de consument worden verkocht?

\subsubsection{Ongecertificeerde bedrijfseigen duurzaamheidsclaims versus externe derde partij CSR labels}

Gosselt et al. (Gosselt et al. 2019) schrijven dat de meeste consumenten positief zijn over maatschappelijk verantwoorde bedrijven. Bij deze bedrijven is effectieve en duidelijke communicatie over hun inspanningen qua Maatschappelijk Verantwoord Ondernemen (MVO, in het Engels Corporate Social Responsibility of CSR) belangrijk. Deze auteurs benoemen in hun artikel dat er een enorme overvloed bestaat aan milieukeurmerken, waarbij bedrijven de beweringen zelf proberen te staven of dit overlaten aan externe derde partijen. Door deze overvloed kunnen consumenten problemen ervaren om de echt duurzame bedrijven te identificeren, wat zou kunnen leiden tot minder effectieve CSR-initiatieven. CSR staat voor de wijze waarop bedrijven sociale, milieu- en economische aspecten integreren in hun waarden, cultuur, beslissingen, strategie en bedrijfsvoering (Gosselt et al. 2019). Daarbij baseren zij zich op de attributietheorie van Kelley (Kelley 1973). Deze theorie onderzoekt de causale onderliggende verklaringen die mensen geven wanneer ze geconfronteerd worden met het gedrag van andere mensen binnen sociale omgevingen (Gosselt et al. 2019; Kelley 1973). De theorie stelt dat individuen waargenomen gedrag toeschrijven aan ofwel aan iemands gemoedstoestand (bijv. een kenmerk) of aan externe beperkingen (bijv. situationele factoren). Het intern toeschrijven maakt dat individuen zich focussen op interne motieven wanneer ze zoeken naar verklaringen voor bepaald gedrag. Aan de andere kant leidt het extern toeschrijven tot een focus op externe motieven bij individuen, waarbij ze gedrag toeschrijven aan externe factoren. Dit proces van toeschrijven doen mensen ook bij de evaluatie van een bedrijf (Gosselt et al. 2019; Weiner 2000). Wanneer consumenten intern toeschrijven geloven ze dat een bedrijf deelneemt aan CSR vanwege hun oprechte belangstelling en zorgen om het milieu. Dit in tegenstelling tot consumenten die extern toeschrijven, want die consumenten kunnen concluderen dat een bedrijf deelneemt aan CSR vanwege situationele factoren, zoals druk vanuit de markt (Gosselt et al. 2019). Daarnaast kan de overheid ook 
druk veroorzaken: we zien dat in de veehouderij steeds vaker de discussie over de "license to operate" wordt gevoerd.

In het algemeen is het zo dat wanneer consumenten blootgesteld worden aan een interne CSR claim en verder geen informatie hebben, zoals een geverifieerde derde partij label (extern label), ze meer kans hebben om de communicatie toe te schrijven aan de huidige duurzaamheidstrend, welke wordt waargenomen als een extrinsiek motief (Gosselt et al. 2019; Parguel et al. 2011). Consumenten hebben meer kans op een negatieve houding, overtuigingen en gedragingen richting een organisatie wanneer zij excentrieke motieven, in vergelijking met intrinsieke motieven, toekennen (Becker-Olsen et al. 2006; Ellen et al. 2006; Gosselt et al. 2019; Mohr et al. 1998). De studie van Gosselt et al. (Gosselt et al. 2019) betoogt breed dat een interne claim alleen effectief is in de mate dat het ondersteund is door een extrinsiek CSR label. Een extern CSR label beïnvloedt de reacties van de consument op een bedrijf. Naast het window-effect, de taak om consumenten over de productiewijze te informeren, is er ook sprake van een mirror-werking op de consument. Een ethisch etiket met een stempel van een derde, zorgt voor een positiever sociaal eigenbeeld. Dit aspect moet niet worden onderschat.

De studie geeft reden om aan te nemen dat tot op zekere hoogte consumenten ook intrinsieke motieven kunnen toeschrijven aan ongecertificeerde interne CSR claims, omdat, los van de bron, CSR in zichzelf positief bekeken wordt (Ellen et al. 2006; Gosselt et al. 2019). Gosselt et al. (Gosselt et al. 2019) vinden dan ook dat het daarom des te belangrijker is om betere begeleiding en uitleg te geven aan consumenten met respect voor de status en informatie waarde van verschillende types claims en labels.

Hoewel er veel literatuur te vinden is over het 'groenwaseffect' van groen adverteren hebben Gosselt et al. (Gosselt et al. 2019) daar in hun studie geen aanwijzingen voor gevonden. Ook al was de CSR communicatie inconsistent en werden extrinsieke motieven waargenomen, toch waren consumenten geneigd te denken dat de organisatie oprecht was in het ondersteunen van milieuzaken. Dit is in lijn met wat Kim en Lee (Kim and Lee 2012) in hun onderzoek vonden.

De bevindingen tonen aan dat consumenten nog steeds op een wat naïeve manier liever interne claims als vanzelfsprekend beschouwen dan dat ze vraagtekens zetten bij de authenticiteit ervan. Daarom concluderen deze auteurs (Kim and Lee 2012) dat het belangrijk is om een multilevel beoordelingssysteem te introduceren dat voorziet in zowel positieve als negatieve externe CSR informatie (Gosselt et al. 2019).

\subsection{Voor- en nadelen van het labelen van het voedselproductieproces}

Messer et al. (Messer et al. 2017) hebben de positieve en negatieve aspecten van het labelen van het voedselproductieproces geïdentificeerd. De goede kanten zijn dat, onder toezicht van een daarvoor geschikte derde partij of de overheid, proces labels effectief bij kunnen dragen aan het dichten van de informatiekloof tussen producenten en consumenten, de consument tevreden kunnen stellen voor wat betreft hun vraag naar het uitgebreider en stringenter garanderen van kwaliteitseisen en waarde kunnen creëren voor zowel consumenten als producenten. De slechte kanten van proces labels zijn dat consumenten de labels verkeerd kunnen interpreteren en daardoor op basis van hun persoonlijke voorkeuren ander voedsel kopen. De lelijke kanten van proces labels zijn volgens Messer et al. (Messer et al. 2017) dat het voedsel dat volgens de conventionele productieprocessen is geproduceerd, kan stigmatiseren ondanks dat er geen wetenschappelijk bewijs is dat dit voedsel kwaad kan of een andere samenstelling heeft.

Lusk en Marette (Lusk and Marette 2012) (op cit. (Messer et al. 2017)) toonden aan dat de aandacht van consumenten beperkt is. Aanvullende informatie kan consumenten afleiden en het zoekproces bemoeilijken, waardoor het welzijn van de consument afneemt. Hoewel een bepaald deel van de informatie interessant kan zijn voor sommigen kan een aanvullend label het zoeken omslachtiger maken voor andere consumenten. Het kunnen lezen van labels vergt namelijk een cognitieve inspanning. Bij te veel informatie of wanneer het te moeilijk te interpreteren is, negeren de consumenten het en blijven ze ongeïnformeerd (McCluskey and Swinnen 2004; Messer et al. 2017). 
Volgens Meerburg moeten ethische etiketten vertrouwen wekken, duidelijk zijn en de aanspraken moeten geverifieerd zijn (Meerburg 2004).

De reactie van consumenten op een label en de bereidheid om daar voor te betalen reflecteert zowel hun voorkeuren als hun overtuigingen. Voorkeuren komen over het algemeen vanuit het binnenste van een individu en zijn stabieler (Lusk et al. 2014; Messer et al. 2017), terwijl overtuigingen kneedbaarder zijn en te beïnvloeden zijn door marketing en reclame of ze zijn simpelweg onjuist (Messer et al. 2017). Zo zijn consumenten bijvoorbeeld bereid meer te betalen voor voedsel dat dichterbij geproduceerd is (Grebitus et al. 2013; Messer et al. 2017). Consumenten waarderen het lage aantal voedselkilometers, omdat ze denken dat dit de impact op het milieu verkleint. Vanwege die overtuiging dragen ze onbedoeld bij aan het tegenovergestelde door bijvoorbeeld liever meer te betalen voor tomaten die dichtbij in kassen met een hoog energieverbruik worden geproduceerd (Costanigro et al. 2015; Messer et al. 2017).

Daarom zouden consumenten betrokken moeten worden bij inferentiële verwerking, waarbij de subjectieve overtuigingen van consumenten gebruikt worden om de informatie die een label bevat te interpreteren (Messer et al. 2017). Steenkamp (Steenkamp 1990) vindt dit inferentiële proces vanuit een publiek politiek standpunt onwenselijk (Messer et al. 2017). Aan de andere kant is het volgens Messer et al. niet nodig om de consument erbij te betrekken wanneer het gaat om directe informatie over de relevante kwaliteitsaspecten (Messer et al. 2017).

Proces labels, zoals 'biologisch' en 'fair trade', krijgen onvermijdelijk bepaalde betekenissen toegedicht terwijl het label niet ontworpen is die zaken te communiceren (Messer et al. 2017). Daarnaast wordt er bij een dergelijk label vanuit gegaan dat alle aspecten beter zijn, terwijl dat niet noodzakelijkerwijs het geval is. Kijlstra et al. (2009) beschrijven bijvoorbeeld dat het dioxinegehalte of het gehalte zware metalen in biologische eieren logischerwijs hoger ligt dan bij conventionele eieren vanwege de uitloop, maar dat hier door de sector niet over wordt gecommuniceerd. Dit leidt ertoe dat er risico's voor dergelijke labels kunnen ontstaan, zeker wanneer een dergelijk issue ineens bij de media voor het voetlicht komt.

In tegenstelling tot proces labels leiden voedingswaarde labels slechts beperkt tot inferentiële interpretatie, omdat ze direct communiceren over de uitkomsten (bijvoorbeeld het aantal calorieën) op basis van gekozen ingrediënten en productieprocessen (Messer et al. 2017). Er is daarmee sprake van harde data.

Swinnen et al. (Swinnen et al. 2005) tonen aan dat mensen die niet deskundig zijn, de meeste informatie via de massamedia ontvangen, wat berucht is vanwege de focus op het brengen van 'slecht nieuws' in plaats van 'goed nieuws', want mensen (inclusief journalisten) kennen meer gewicht toe aan 'slecht nieuws' dan aan 'goed nieuws' (Kahneman et al. 1991; Messer et al. 2017; Mizerski 1982). Inprenting door de media kan een enorm sterk effect op de houding van consumenten hebben (Messer et al. 2017) en wanneer de waarnemingen eenmaal gevestigd zijn, hebben mensen de neiging om informatie die tegen de bestaande overtuigingen ingaat te negeren of verkeerd te interpreteren (Messer et al. 2017; Steenkamp 1990), omdat bewezen 'verkeerd' een gevoel van onbehagen en ongemak veroorzaakt (bijv. cognitieve dissonantie, zie (Festinger 1962)) (Messer et al. 2017). Consumenten zijn duidelijk geïnteresseerd in meer kennis over hun voedsel en zijn bereid meer te betalen voor voedsel waarvan zij geloven dat het overeenkomt met hun voorkeuren en waarden (en vermijden voedsel dat dat niet doet) (Messer et al. 2017).

\section{Gevolgen veelheid labels}

Concurrerende labels en bedrijfsprogramma's wekken verwarring bij de consumenten en creëren ruimte voor opportunistisch gebruik of valse claims en groen wassen (Lyon and Montgomery 2015; Mitchell and Papavassiliou 1999). Rueda en haar collega's (Rueda et al. 2017) bediscussiëren dit en zeggen dat de vermenigvuldiging van het aantal private labels en initiatieven in de meeste gevallen niet bedoeld zijn om de consument te desoriënteren, maar een zorgvuldige overweging van de complexe condities waaronder de agri-food leveranciersketen opereert. Echter, als er teveel labels zijn loop je de kans dat het vertrouwen van consumenten in labels sterk afneemt en men uiteindelijk kiest voor een meer gangbaar type product. 


\section{$4 \quad$ Resultaten interviews}

\subsection{Resultaten}

Beide geïnterviewde rundveehouders geven aan een onafhankelijke 'maatlat' ofwel integraal keurmerk systeem te willen. Daar moet de overheid volgens hen voor zorgen, gevoed door kennis vanuit de wetenschap. Een van de geïnterviewden noemt daarbij als voorbeeld het Energielabel.

Beide veehouders steken niet in op het actief laten participeren van burgers. Zij willen dat de burgerconsument meer en betere informatie krijgt, zodat die beter weet waar het geproduceerde rundvlees vandaan komt en aan welke duurzaamheidseisen het voldoet. Op basis van die eerlijke en transparante voorlichting koopt de burger-consument vervolgens volgens hen meer rundvlees. De rol van de burger-consument blijft bij beide geïnterviewden beperkt tot het bewuster kiezen en kopen van rundvlees dat aan dat nieuwe keurmerk voldoet. Van echte burgerparticipatie is hier dus geen sprake.

Er zijn een aantal belangrijke problemen die de twee geïnterviewden ervaren bij de totstandkoming van een duurzaamheidskeurmerk voor de rundvleessector. Dit zijn:

- Het gebrek aan samenwerking tussen de boeren onderling.

- De rundvleessector heeft geen belangenbehartiger.

- De overheid heeft het Beter Leven Keurmerk al als duurzaamheidskeurmerk omarmd, maar een certificerende instantie als KIWA voert geen controles uit op het voldoen aan de eisen. Bovendien zijn de eisen alleen gericht op dierenwelzijn en niet op integrale duurzaamheid.

- De rol van de grossier in de keten. Die heeft als 'tussenhandelaar' geen belang bij een maatlat/keurmerk. De grossier haalt bijvoorbeeld rechtstreeks bij de slachterijen 'dubbeldoel melkkoevlees'. Maar dan alleen het vlees dat goed verkoopt zoals ossenhaas. De vierkantsverwaarding ontbreekt daardoor en het product is bovendien van minder goede kwaliteit dan vlees van melkkoeien die eerst afgemest zijn. De consument klaagt echter vervolgens wel rechtstreeks bij de 'Dubbeldoel melkkoevlees' producent, omdat het onder de naam 'dubbeldoel melkkoevlees' gekocht is.

- $\quad$ Slagers willen bij voorkeur delen van het dier met een hoog uitsnijrendement.

- Aan de andere kant moet de sector ook de hand in eigen boezem steken. De sector heeft al jaren niet meer het volume in constante kwaliteit die de supermarkt vraagt.

- De veehouder kan bewust duurzame keuzes maken, maar wanneer de gevolgen van die keuzes onbekend zijn bij de consument dan ontstaat er geen vraag naar het product en is het lastig om de kosten die de veehouder maakt voor de duurzame productiewijze terug te verdienen.

- In agrarische sector moet iedereen mee kunnen komen. Er is onvoldoende duidelijkheid, transparantie, geen eerlijk speelveld en onvoldoende onderscheid in beloning tussen boeren die echt duurzaam boeren en boeren die dat niet doen.

- Commerciële partijen lobbyen volgens de geïnterviewden continu in Den Haag wat geen positieve weerslag heeft op de duurzaamheid.

- De agrarische sector zit in een vicieuze cirkel, acteert passief en legt veel schuld bij de buitenwereld.

- Wet- en regelgeving die bedacht is voor het beteugelen van de problemen binnen de gangbare veehouderij kunnen belemmerend zijn voor boeren die werken aan duurzame oplossingen, zoals een gesloten bedrijfssysteem. 


\subsection{Quotes}

Hieronder staan een aantal relevante en illustratieve quotes uit de interviews met de twee in het onderzoek participerende rundveehouders:

Quotes uit interview met rundveehouder I:

'Alle landbouwproducten moet je eigenlijk tegen dezelfde maatlat gaan leggen, zoals nu ook de energielabels van bijvoorbeeld elektronicaproducten voor in het huishouden. Dan wordt het voor de consument heel gemakkelijk en heel overzichtelijk en voor de boer ook.'

'Je moet naar een integrale benadering gaan, waarbij de overheid aan die maatlat subsidies kan verstrekken. We moeten met elkaar die maatlat inzichtelijk maken. Wat willen we niet, wat willen we wel en hoe ziet dat eruit. Dat moet onafhankelijk en overzichtelijk en op een gegeven moment moet de boer klimmen in zijn ladder. En klimt hij in zijn ladder, dan krijgt hij iets meer compensatie vanuit de overheid en krijgt hij een betere vergoeding voor zijn product.'

'We moeten gaan stimuleren wat goed gaat en we moeten gaan remmen waar het fout gaat. En op een gegeven moment heb je gewoon hele grote intensieve bedrijven, die zijn gewoon milieubelastend, maar door hun bedrijfssysteem wel winstgevend. Dat is een keuze, maar hangt er een label aan jouw product die daar bij hoort. En daar staan de vergoedingen ook tegenover.'

'Er wordt heel vaak gedacht: die klant die bij jullie koopt, die is daar heel bewust van. Dat is de yup, die weet precies wat die wil hebben. Die vind dat interessant. De ervaring leert dat alle pluimages komen en het bijzondere is best wel veel van de onderkant van de samenleving. Mensen die weinig te besteden hebben. Die bewust bij ons producten kopen omdat ze een gezond leven willen leiden of in ieder geval het enige wat ze kunnen doen is hun gezin gezonde voeding geven en uiteindelijk duurzaamheid ook belangrijk vinden.'

'En als je puur naar vragen van consumenten gaat kijken. Die zijn er zeker wel. Maar dat is vooral het niveau van hoe wordt het product verwerkt. Het slachtproces en wie verwerkt het dan verder. Of er ook andere onderdelen beschikbaar zijn, groot en klein. Dat niveau.'

'De klant wordt gewoon via onze website geïnformeerd, via nieuwsbrieven wordt die geïnformeerd van wat wij doen. En wij hebben natuurlijk zo'n transparant systeem, dat de klant daar niet veel vragen over heeft. Die hoeft niet te vragen of wij iets toevoegen aan onze bedrijfsvoering. Nee, want wij hebben een gesloten systeem, dus wij voegen niks toe en uiteindelijk is dat ook de kracht van het bedrijf.'

'Kijk de consument, de klant gaat participeren door bewust te kopen. Kijk zelf maar. Als jij nu een nieuwe wasmachine gaat kopen. Dat doe jij niet eens bewust, maar jij zou nooit een $F$ wasmachine kopen. Je zou altijd een AA of een $A$ of een $A+$ nemen. Als het prijsverschil zo groot is, dan pak je een B.'

'Op het moment dat wij als Nederland laten zien: wij zijn in staat om een duurzaam product te produceren, een product die een minder hoge voetafdruk heeft op de wereld, dan gaan mensen volgen. Je moet ergens zeggen: hier gaan we het doen. Wij gaan laten zien dat dit gaat werken en ook: hier in Nederland hebben wij een staffel gemaakt. Net zo als met energie, die staffel hebben we in de landbouw. Ben je als boer niet duurzaam, kom je onderaan die staffel. Wij willen dat Europa dat gaat overnemen.'

'De consument wil wel. Echt wel. Daar ben ik heilig van overtuigd. Dat is een heel natuurlijk proces. Uiteindelijk binnen 2 jaar verkoop je alleen maar klasse B en A producten.' 


\section{Quotes uit interview met rundveehouder II:}

'Ik denk dat de consument bewustere keuzes gaat maken als hij beter geïnformeerd wordt. Ik zie nu in de supermarkt nooit iemand onder op het pakje kijken, terwijl daar wel alle herkomstinformatie staat. En nu wil ik niet uitdragen 'in vlees uit Uruguay zitten groeihormonen', maar ik wil wel uitdragen 'als je kiest voor Nederland, dan kies je voor dit en dit en dit. Dan steun je de boeren.' En die informatieverstrekking moet onafhankelijk zijn en ergens centraal bereikbaar, zonder dat dat hangt aan een Dierenbescherming of een Centraal Bureau voor de Levensmiddelen (CBL) of wat dan ook. Moet eigenlijk gevoed worden met informatie vanuit de sector, vanuit de praktijk.' 'Enerzijds heel belangrijk dat de burger-consument betrokken wordt bij het kiezen van de duurzaamheidseisen, want wij weten misschien helemaal niet waar die naar op zoek is. Maar anderzijds misschien ook de wetenschap om te wegen 'wat is duurzamer dan iets anders'.'

'Wij hebben hier ook 3 bussen met klanten gehad van het slagerschap, met echt de consumenten in de stal. En aan het einde van de 3 dagen waarbij we elke dag 50 mensen ontvingen, zeiden die mensen 'wat wij hier zien, is helemaal niet wat in de krant staat. Hoe kan dat nou zo'n groot verschil zijn.' Dus er valt een wereld te winnen.'

'Wij hebben natuurlijk met het vlees van die melkkoeien een concept waar AH ook een marktaandeel mee kan bewerkstelligen en ver vooroplopen in verduurzaming in het schap. Wij hebben onderzoek van een adviesbureau waaruit blijkt dat het vlees van deze koeien aanzienlijk minder $\mathrm{CO}_{2}$ uitstoot dan het Ierse vlees dat ze tot nu toe hebben gekocht. Daar kunnen zij wat mee en die handvatten kunnen wij ze geven. Dan kun je samen optrekken.'

'Ik vind je moet altijd produceren wat gevraagd wordt. Dus als een klant een idee heeft wat bij ons past en wat goed is voor de dieren, dan zou ik het altijd doen.'

'Wij hebben een flyer hebben gemaakt van duurzaamheidskenmerken van hoe onze veehouderij werkt en onze slagers delen die uit aan hun klanten.'

'Als we het hebben over die burgerparticipatie dan denk ik dat daarin de sleutel van het succes ligt. Als je die burger-consument bewust kunt maken van z'n keuzes. En je gaat met $z^{\prime} n$ allen uitdragen wat de voordelen zijn van Nederlands rundvlees dan ligt de hele wereld open voor succes.'

'Wij merken wel dat die slagers die iedere week uit onze stal, nou niet persé uit onze stal, maar iedere week uit een stal een koe krijgen, dat die ten eerste gaan groeien in hun rundvleesomzet. En dat zij beter worden uitgedaagd om die hele koe te verwaarden. Dus bijvoorbeeld iemand komt in de winkel en vraagt om sukadelap en die is op, dan zegt die slager van 'ik heb dit beestje, maar ik heb daar nog wel riblappen van bijvoorbeeld. En dan gaat die mevrouw met riblappen naar huis.' 


\section{Discussie en conclusie}

De kernvragen uit dit onderzoek waren:

1) Hoe kan de consument betrokken worden in de beoordeling/verbetering van duurzaamheidskeurmerken?

2) Hoe kan de consument betrokken worden bij het meten van duurzaamheid?

Vanuit bovenstaande kernvragen werd de praktische vertaalslag gemaakt naar de rundveehouderij. Opvallend vonden wij dat op dit moment consumenten nog niet of nauwelijks betrokken zijn bij duurzaamheidscertificering door derde partijen en dat dit veel vaker door NGO's wordt gedaan. Nadeel voor integrale verduurzaming hiervan is dat NGO's vaak zijn opgericht met een bepaalde focus (milieu, dierwelzijn of anderszins) en dat de integraliteit hierdoor vaak ontbreekt. Dit maakt het voor consumenten lastig om op betrouwbare wijze een inschatting te maken of daadwerkelijk aan duurzaamheid is voldaan of dat het hier slechts specifieke onderdelen betreft. Deze onduidelijkheid heeft repercussies: dit zal er uiteindelijk toe leiden dat consumenten de keurmerken minder vertrouwen, omdat de achtergronden ervan onduidelijk zijn of er te weinig over is gecommuniceerd.

Het werken in Values-Based Supply Chains is een mogelijkheid die ook in Nederland perspectief kan bieden. Onder meer de Nederlandse Food hub, het Wroetvarken en Natuurvlees Westerkwartier zijn hier in zekere zin voorbeelden van. Ook is er recent een online platform voor een voedselcoöperatie bedacht (Bregje Hamelinck). Voordeel van dit soort VBSC's is dat er allerlei eisen aan deelnemende boeren kunnen worden gesteld met betrekking tot hun productiewijze (bijv. wel of niet biologisch). Het zou ons inziens waardevol zijn als de eerder beschreven methode van Yin (Yin 2009) ook zou worden ingezet om een aantal Nederlandse vlees- of zuivelketens te analyseren en vervolgens ook te toetsen aan de wetenschappelijke literatuur of de verdere ontwikkeling van VBSC's in Nederland haalbaar is.

Het koppelen van duurzaamheidsthema's binnen de voedselproductie aan een educatieprogramma voor kinderen zou een fraaie ontwikkeling kunnen zijn om consumenten al op jonge leeftijd bewust te maken van dilemma's rond duurzaamheid. Dit wordt ook gesuggereerd door de auteurs Feenstra en Hardesty (Feenstra and Hardesty 2016). Hier zou dan ook een thema als biodiversiteit aanvullend aan te koppelen zijn. Door een dergelijke actie kunnen kinderen al via een vorm van citizen science leren over voedsel en duurzaamheid. Op dit moment zijn in Nederland ook dit soort plannen (bijvoorbeeld vanuit de stichting De Nieuwe Leefstijl) en krijgt het vorm via de Raad van Kinderen.

Naast vroegtijdige educatie over voedsel en de duurzaamheid van het productieproces is het wenselijk om te werken aan integrale methoden om duurzaamheid te meten en tevens de burgerconsument bewust te maken van de grote nuances die hierin zitten. Want wanneer je maatregelen in de het voedselsysteem of de keten beoordeelt op hun duurzaamheid, vraagt dat om radicale nuance. Hoe graag we het ook willen, een schijnbaar eenvoudige maatregel heeft namelijk in de complexe voedselkringloop eigenlijk nooit een simpele uitwerking. Dat bleek bijvoorbeeld uit een uitgebreide case-studie naar de effecten van een verbod op niet-Europese grondstoffen voor veevoer met behulp van de Kringlooptoets (Bremmer et al. 2021).

Zo moet de import van veevoergrondstoffen worden bekeken in relatie tot onder andere de import van humane voeding, verschuivingen van productie naar ander plekken op de wereld, verhoging van het gebruik van kunstmest, intensivering van productie en op mogelijke veranderingen in het humane dieet. En daarbij hoort dan ook nog een afweging met de economische effecten. Verder blijkt meer specifiek uit interviews dat samenwerking binnen de veehouderijsector ook belangrijk is. Nieuwe initiatieven moeten niet per definitie worden beoordeeld als bedreigend door de traditioneel georiënteerde sectorvertegenwoordiging, maar het biedt volgens de geïnterviewden juist kansen als dit op positieve wijze tegemoet worden getreden. 
En over wat duurzaam is, daarover zullen stakeholders met elkaar in gesprek moeten. Een gesprek waarin ze samen accepteren dat het effect van ingrepen in het voedselsysteem genuanceerder ligt dan je op het eerste gezicht verwacht. Hiervoor is een gespreksinstrument zoals bijvoorbeeld de eerdergenoemde Kringlooptoets een middel, maar ook andere instrumenten kunnen helpen om aan duurzaamheidsdoelen te werken en het gesprek tussen verschillende partijen (agrarische sector, overheden, NGOs en burgers/consumenten) te voeren. Een eerste stap zou kunnen zijn om per keten een consumentenpanel te vormen om zo mee te kunnen discussiëren over de definities van duurzaamheid. Dit kan het bedrijfsleven zelf organiseren, of een NGO of de overheid.

Kortom:

1. Kijk of het denken in Values-based Supply Chains ook in Nederland kan werken. Maak een analyse voor een aantal Nederlandse vlees- of zuivelketens en toets deze aan de wetenschappelijke literatuur;

2. Koppel duurzaamheidsthema's rondom voedsel aan educatieprogramma's voor kinderen via scholen;

3. Probeer naast economische en ecologische duurzaamheid, ook de maatschappelijke duurzaamheid beter te verankeren in keurmerken?;

4. Gebruik een gespreksinstrument om met verschillende partijen te werken aan duurzaamheidsdoelen en vorm een consumentenpanel per keten om zo keurmerken beter aan te laten sluiten bij consumenten. 


\section{Literatuur}

Adam KL (2006) Community supported agriculture. ATTRA-National Sustainable Agriculture Information Service Butte, MT,

Arnstein SR (1969) A ladder of citizen participation Journal of the American Institute of planners 35:216-224

Bain C, Hatanaka M (2010) The practice of third-party certification: enhancing environmental sustainability and social justice in the global south? In: Calculating the social. Springer, pp 56-74

Bakker-Smit G (2018) Hoe kijkt de burger ernaar? Presentatie tijdens het Symposium Biodiversiteit. Rabobank Nederland, Dairy Campus, Leeuwarden

Becker-Olsen KL, Cudmore BA, Hill RP (2006) The impact of perceived corporate social responsibility on consumer behavior Journal of business research 59:46-53

Blättel-Mink B, Boddenberg M, Gunkel L, Schmitz S, Vaessen F (2017) Beyond the market-New practices of supply in times of crisis: The example community-supported agriculture International Journal of Consumer Studies 41:415-421 doi:https://doi.org/10.1111/ijcs.12351

Boström M, Jönsson AM, Lockie S, Mol AP, Oosterveer P (2015) Sustainable and responsible supply chain governance: challenges and opportunities Journal of Cleaner Production 107:1-7

Bremmer B, van Eijk O, Vellinga T, te Pas C, Scholten J, Meerburg B, Verburg C (2021) Kringloopeffecten van het stoppen van import van diervoedergrondstoffen van buiten de EU: Verkenning met behulp van de KringloopToets. Wageningen Livestock Research,

Brown C (2003) Consumers' preferences for locally produced food: A study in southeast Missouri American Journal of Alternative Agriculture 18:213-224

Brown JJ, Reingen PH (1987) Social ties and word-of-mouth referral behavior Journal of Consumer research $14: 350-362$

Busch L (2011) The private governance of food: equitable exchange or bizarre bazaar? Agriculture and Human Values 28:345-352

Bush IG, Gillson A, Hamilton M, Perrin M (2005) Public participation - drawing the boundaries Water and Environment Journal 19:181-188 doi:https://doi.org/10.1111/j.1747-6593.2005.tb01585.x

Bush SR, Toonen H, Oosterveer P, Mol AP (2013) The 'devils triangle'of MSC certification: Balancing credibility, accessibility and continuous improvement Marine Policy 37:288-293

Chiffoleau Y, Millet-Amrani S, Canard A (2016) From short food supply chains to sustainable agriculture in urban food systems: Food democracy as a vector of transition Agriculture 6:57

Chopyak J, Levesque P (2002) Public participation in science and technology decision making: trends for the future Technology in Society 24:155-166 doi:https://doi.org/10.1016/S0160-791X(01)00051-3

Cooperrider DL, Whitney D (2002) A Positive Revolution in Change: Appreciative Inquiry. In: Handbook of Organizational Behavior, Revised and Expanded 2nd Edition. Routledge, p 20

Costanigro M, Deselnicu O, Kroll S (2015) Food beliefs: Elicitation, estimation and implications for labeling policy Journal of Agricultural Economics 66:108-128

Costerus M (2020) Rauwe melk beschermt mogelijk tegen virusinfectie. Reformatorisch Dagblad. 2021

Cox R, Holloway L, Venn L, Dowler L, Hein JR, Kneafsey M, Tuomainen H (2008) Common ground? Motivations for participation in a community-supported agriculture scheme Local environment 13:203-218

Davis KF, Gephart JA, Emery KA, Leach AM, Galloway JN, D'Odorico P (2016) Meeting future food demand with current agricultural resources Global Environmental Change 39:125-132

De Olde E, van der Linden A, olde Bolhaar L, de Boer I (2020) Sustainability challenges and innovations in the Dutch egg sector Journal of Cleaner Production 258:120974

De Olde EM, Sautier M, Whitehead J (2018) Comprehensiveness or implementation: Challenges in translating farm-level sustainability assessments into action for sustainable development Ecological Indicators 85:1107-1112

Ellen PS, Webb DJ, Mohr LA (2006) Building corporate associations: Consumer attributions for corporate socially responsible programs Journal of the academy of Marketing Science 34:147-157

Feenstra G, Hardesty S (2016) Values-based supply chains as a strategy for supporting small and mid-scale producers in the United States Agriculture 6:39 
Feenstra G, Visher D, Hardesty S (2011) Developing Values-Based Distribution Networks to Enhance the Prosperity of Small and Medium Sized Producers. Davis, California: University of California Agricultural Sustainability ...,

Festinger L (1962) Cognitive dissonance Scientific American 207:93-106

Fouilleux E, Loconto A (2017) Voluntary standards, certification, and accreditation in the global organic agriculture field: a tripartite model of techno-politics Agriculture and Human Values 34:1-14

Freedman S, Jin GZ (2008) Do social networks solve information problems for peer-to-peer lending? Evidence from Prosper. com

Gosselt JF, van Rompay T, Haske L (2019) Won't get fooled again: The effects of internal and external CSR ECO-labeling Journal of business ethics 155:413-424

Grebitus C, Lusk JL, Nayga Jr RM (2013) Effect of distance of transportation on willingness to pay for food Ecological economics 88:67-75

Hanson KL et al. (2019) Knowledge, attitudes, beliefs and behaviors regarding fruits and vegetables among cost-offset community-supported agriculture (CSA) applicants, purchasers, and a comparison sample Nutrients 11:1320

Hatanaka M (2010a) Certification, partnership, and morality in an organic shrimp network: rethinking transnational alternative agrifood networks World Development 38:706-716

Hatanaka M (2010b) Governing sustainability: examining audits and compliance in a third-party-certified organic shrimp farming project in rural Indonesia Local Environment 15:233-244

Henderson E, Van En R (2007) Sharing the harvest: a citizen's guide to Community Supported Agriculture. Chelsea Green Publishing,

Herr PM, Kardes FR, Kim J (1991) Effects of word-of-mouth and product-attribute information on persuasion: An accessibility-diagnosticity perspective Journal of consumer research 17:454-462

Johnston J (2008) The citizen-consumer hybrid: ideological tensions and the case of Whole Foods Market Theory and society 37:229-270

Kahneman D, Knetsch JL, Thaler RH (1991) Anomalies: The endowment effect, loss aversion, and status quo bias Journal of Economic perspectives 5:193-206

Keijzers G, Jeurissen R (2002) Duurzaam ondernemen: toekomstethiek in dialoog. Kluwer,

Kelley HH (1973) The processes of causal attribution American psychologist 28:107

Kennedy A, Liljeblad J (2016) Food systems governance: Challenges for justice, equality and human rights. Routledge,

Kijlstra A, Meerburg B, Bos A (2009) Food safety in free-range and organic livestock systems: Risk management and responsibility Journal of Food Protection 72:2629-2637

Kim S, Lee Y-J (2012) The complex attribution process of CSR motives Public Relations Review 38:168-170

Kneafsey M, Dowler E, Lambie-Mumford H, Inman A, Collier R (2013) Consumers and food security: Uncertain or empowered? Journal of Rural Studies 29:101-112

Kok A, de Olde E, de Boer I, Ripoll-Bosch R (2020) European biodiversity assessments in livestock science: A review of research characteristics and indicators Ecological Indicators 112:105902

Lindgren E et al. (2018) Sustainable food systems-a health perspective Sustainability Science 13:15051517 doi: $10.1007 / \mathrm{s} 11625-018-0586-x$

Loconto A (2014) Sustaining an enterprise, enacting sustainabilitea Science, Technology, \& Human Values 39:819-843

Loconto A (2015) Assembling governance: the role of standards in the Tanzanian tea industry Journal of Cleaner Production 107:64-73

Loconto A (2017) Models of Assurance: Diversity and Standardization of Modes of Intermediation The ANNALS of the American Academy of Political and Social Science 670:112-132 doi: $10.1177 / 0002716217692517$

Loconto A, Busch L (2010) Standards, techno-economic networks, and playing fields: Performing the global market economy Review of International Political Economy 17:507-536 doi: $10.1080 / 09692290903319870$

Loconto A, Hatanaka M (2018) Participatory guarantee systems: Alternative ways of defining, measuring, and assessing 'sustainability' Sociologia Ruralis 58:412-432

Lundmark F, Berg C, Röcklinsberg H (2018) Private animal welfare standards-opportunities and risks Animals 8:4

Lusk JL, Marette S (2012) Can labeling and information policies harm consumers? Journal of agricultural \& food industrial organization 10 
Lusk JL, Roosen J, Bieberstein A (2014) Consumer acceptance of new food technologies: causes and roots of controversies Annu Rev Resour Econ 6:381-405

Lynam T, De Jong W, Sheil D, Kusumanto T, Evans K (2007) A review of tools for incorporating community knowledge, preferences, and values into decision making in natural resources management Ecology and society 12

Lyon TP, Montgomery AW (2015) The means and end of greenwash Organization \& Environment 28:223-249

Lytton TD (2014) Competitive third-party regulation: How private certification can overcome constraints that frustrate government regulation Theoretical Inquiries in Law 15:539-572

McCluskey JJ, Swinnen JF (2004) Political economy of the media and consumer perceptions of biotechnology American Journal of Agricultural Economics 86:1230-1237

Meerburg BG (2004) Maatschappelijk verantwoord ondernemen: een kans voor de keten! . In: De toekomstige innovatie-agenda voor ketens en netwerken Stichting AKK, https://edepot.wur.nl/33223, pp 8-15

Messer KD, Costanigro M, Kaiser HM (2017) Labeling food processes: the good, the bad and the ugly Applied Economic Perspectives and Policy 39:407-427

Mitchell VW, Papavassiliou V (1999) Marketing causes and implications of consumer confusion Journal of Product \& Brand Management

Mizerski RW (1982) An attribution explanation of the disproportionate influence of unfavorable information Journal of consumer research 9:301-310

Mohr LA, Eroğlu D, Ellen PS (1998) The development and testing of a measure of skepticism toward environmental claims in marketers' communications Journal of consumer affairs 32:30-55

Parguel B, Benoît-Moreau F, Larceneux F (2011) How sustainability ratings might deter 'greenwashing': A closer look at ethical corporate communication Journal of business ethics 102:15-28

Paul M (2019) Community-supported agriculture in the United States: Social, ecological, and economic benefits to farming Journal of Agrarian Change 19:162-180 doi:https://doi.org/10.1111/joac.12280

Perényi Z, Iserte M, Paun G, Valeška MV (2016) Be part of CSA! Supporting booklet for training on community supported agriculture. https://urgenci.net/wp-content/uploads/2016/05/Overview-ofCommunity-Supported-Agriculture-in-Europe-F.pdf. Accessed 10-12-2020 2020

Pettenati G, Toldo A, Ferrando T (2018) The food system as a commons. In: Routledge handbook of food as a commons. Routledge, pp 42-56

Peuker B (2018) Protection of a place?: Community supported agriculture (CSA) in Germany. In: Localizing Global Food. Routledge, pp 176-189

Pimbert M (2012) Fair and sustainable food systems: from vicious cycles to virtuous circles

Ponte S, Cheyns E (2013) Voluntary standards, expert knowledge and the governance of sustainability networks Global Networks 13:459-477

Porter ME, Van der Linde C (1995) Toward a new conception of the environment-competitiveness relationship Journal of economic perspectives 9:97-118

Power M (1997) The audit society: Rituals of verification. OUP Oxford,

Raban O (2010) The fallacy of legal certainty: why vague legal standards may be better for capitalism and liberalism. Boston University Public Interest Law Journal:175-191

Ramirez R (1999) Value co-production: intellectual origins and implications for practice and research Strategic management journal 20:49-65

Ransom E, Hatanaka M, Konefal J, Loconto A (2017) Science and standards The Routledge Handbook of the Political Economy of Science New York: Routledge:329-340

Renting H, Schermer M, Rossi A (2012) Building food democracy: Exploring civic food networks and newly emerging forms of food citizenship The International Journal of Sociology of Agriculture and Food 19:289-307

Rueda X, Garrett RD, Lambin EF (2017) Corporate investments in supply chain sustainability: Selecting instruments in the agri-food industry Journal of cleaner production 142:2480-2492

Sacchi G (2019) Social innovation matters: The adoption of participatory guarantee systems within Italian alternative agri-food networks Strategic Change 28:241-248

Schlosser AE (2011) Can including pros and cons increase the helpfulness and persuasiveness of online reviews? The interactive effects of ratings and arguments Journal of Consumer Psychology 21:226239

Scholes RJ et al. (2018) IPBES (2018): Summary for policymakers of the assessment report on land degradation and restoration of the Intergovernmental Science- Policy Platform on Biodiversity and 
Ecosystem Services. Intergovernmental Science-Policy Platform on Biodiversity and Ecosystem

Services, Bonn, Germany

Siebens H (2002) Concepts and Working Instruments for Corporate Governance Journal of Business Ethics 39:109-116 doi:10.1023/A:1016340219437

Sitnikov CS, Bocean CG (2012) Corporate social responsibility through the lens of ISO standards Business Excellence and Management 2:56-66

Sonnino R, Marsden T (2006a) Alternative food networks in the south west of England: towards a new agrarian eco-economy? In: Between the local and the global. Emerald Group Publishing Limited,

Sonnino R, Marsden T (2006b) Beyond the divide: rethinking relationships between alternative and conventional food networks in Europe Journal of economic geography 6:181-199

Soper K (2007) Re-thinking theGood Life: The citizenship dimension of consumer disaffection with consumerism Journal of Consumer Culture 7:205-229

Steenkamp J-BE (1990) Conceptual model of the quality perception process Journal of Business research 21:309-333

Sultan F, Farley JU, Lehmann DR (1990) A meta-analysis of applications of diffusion models Journal of marketing research 27:70-77

Swedberg R, Granovetter M (2001) Introduction to the second edition The sociology of economic life 2:1-31

Swinnen JF, McCluskey J, Francken N (2005) Food safety, the media, and the information market Agricultural Economics 32:175-188

Toffler A (1980) The third wave vol 484. Bantam books New York,

Vaarst M, Steenfeldt S, Horsted K (2015) Sustainable development perspectives of poultry production World's poultry science journal 71:609-620

Van der Ploeg JD, Jingzhong Y, Schneider S (2012) Rural development through the construction of new, nested, markets: comparative perspectives from China, Brazil and the European Union Journal of Peasant Studies 39:133-173

Vasquez A, Sherwood NE, Larson N, Story M (2017) Community-supported agriculture as a dietary and health improvement strategy: A narrative review Journal of the Academy of Nutrition and Dietetics 117:83-94

Weiner B (2000) Attributional thoughts about consumer behavior Journal of Consumer research 27:382-387 Yin RK (2009) Case study research: Design and methods vol 5. sage,

Zwick D, Bonsu SK, Darmody A (2008) Putting Consumers to Work: Co-creationand new marketing governmentality Journal of consumer culture 8:163-196 


\section{Bijlage 1 Vragenlijst semi-gestructureerd interview met rundveehouders}

\section{De vragen aan de rundveehouders die producten verkopen onder een eigen boerderijlabel (al dan niet met een keurmerk):}

Op uw website zag ik dat u ......(producten noemen) verkoopt. Wat maakt dat u gekozen heeft voor de verkoop van deze producten?

Kunt $u$ iets vertellen over de productiewijze? (Of noemen wat je daarover op de website hebt gelezen).

Wat maakt dat u gekozen heeft voor deze productiewijze?

Welke (duurzaamheids)eisen stelt u zelf aan uw producten en productiewijze?

Waarom heeft u voor die eisen gekozen? (Welke kansen zag/ziet u?)

Wilt $\mathrm{u}$ in de nabije toekomst gaan voldoen aan nieuwe duurzaamheidseisen? Zo ja, is dat dan vanuit de markt / consument-burger of de overheid gedreven?

Aan welke duurzaamheidseisen kunt of wenst u niet te voldoen? Waarom niet? (Welke belemmeringen ervaart u?)

Hoe vermarkt u uw producten en productiewijze? Gebruikt u de (duurzaamheids)eisen die u daarbij zelf stelt als 'claims'?

Hoe garandeert u de claims die u zelf aan uw producten hangt? Of: hoe garandeert u dat uw producten aan de eisen voldoen die u zelf stelt? Maakt u bijvoorbeeld gebruik van een keurmerk of vorm van certificering? (Biologisch is bijvoorbeeld zo'n term)

Welke kansen ziet u voor duurzaamheidscertificering? En welke belemmeringen?

Welke invloed heeft de klant op de producten die u maakt/ verkoopt? En op de productiewijze?

Vraagt $u$ de klant naar hun mening over uw producten? Of is de klant op andere wijze bij het bedrijf, de productie betrokken?

Zou u willen dat de klant of de burger participeert in hoe uw producten tot stand komen en/of vermarkt worden? Zo ja, waarom en op welke manier? Zo nee, waarom niet?

Wanneer bent $\mathrm{u}$ bereidt de productiewijze of het product aan te passen voor de klant? En wanneer juist niet? 




Wageningen Livestock Research Postbus 338

$6700 \mathrm{AH}$ Wageningen

T 0317483953

E info.livestockresearch@wur.nl www.wur.nl/livestock-research
Wageningen Livestock Research ontwikkelt kennis voor een zorgvuldige en renderende veehouderij, vertaalt deze naar praktijkgerichte oplossingen en innovaties, en zorgt voor doorstroming van deze kennis. Onze wetenschappelijke kennis op het gebied van veehouderijsystemen en van voeding, genetica, welzijn en milieu-impact van landbouwhuisdieren integreren we, samen met onze klanten, tot veehouderijconcepten voor de $21 \mathrm{e}$ eeuw.

De missie van Wageningen University \& Research is 'To explore the potential of nature to improve the quality of life'. Binnen Wageningen University \& Research bundelen 9 gespecialiseerde onderzoeksinstituten van Stichting Wageningen Research en Wageningen University hun krachten om bij te dragen aan de oplossing van belangrijke vragen in het domein van gezonde voeding en leefomgeving. Met ongeveer 30 vestigingen, 6.500 medewerkers en 10.000 studenten behoort Wageningen University \& Research wereldwijd tot de aansprekende kennisinstellingen binnen haar domein. De integrale benadering van de vraagstukken en de samenwerking tussen verschillende disciplines vormen het hart van de unieke Wageningen aanpak. 